\title{
Fine root dynamics for forests on contrasting soils in the Colombian Amazon
}

\author{
E. M. Jiménez ${ }^{1}$, F. H. Moreno ${ }^{2}$, M. C. Peñuela ${ }^{1}$, S. Patiño ${ }^{1,3}$, and J. Lloyd ${ }^{3, *}$ \\ ${ }^{1}$ Grupo de Ecología de Ecosistemas Terrestres Tropicales, Universidad Nacional de Colombia Sede Amazonia, Instituto \\ Amazónico de Investigaciones-Imani, km. 2, vía Tarapacá, Leticia, Amazonas, Colombia \\ ${ }^{2}$ Grupo de Bosques y Cambio Climático, Universidad Nacional de Colombia Sede Medellín, Ápartado Aéreo 1779, \\ Medellín, Colombia \\ ${ }^{3}$ Earth and Biosphere Institute, School of Geography, University of Leeds, LS2 9JT, UK \\ * previously at: Max Planck Institute fuer Biogeochemie, Jena, Germany
}

Received: 9 January 2009 - Published in Biogeosciences Discuss.: 30 March 2009

Revised: 29 September 2009 - Accepted: 2 November 2009 - Published: 3 December 2009

\begin{abstract}
It has been hypothesized that as soil fertility increases, the amount of carbon allocated to below-ground production (fine roots) should decrease. To evaluate this hypothesis, we measured the standing crop fine root mass and the production of fine roots $(<2 \mathrm{~mm})$ by two methods: (1) ingrowth cores and, (2) sequential soil coring, during 2.2 years in two lowland forests growing on different soils types in the Colombian Amazon. Differences of soil resources were defined by the type and physical and chemical properties of soil: a forest on clay loam soil (Endostagnic Plinthosol) at the Amacayacu National Natural Park and, the other on white sand (Ortseinc Podzol) at the Zafire Biological Station, located in the Forest Reservation of the Calderón River. We found that the standing crop fine root mass and the production was significantly different between soil depths $(0-10$ and $10-20 \mathrm{~cm})$ and also between forests. The loamy sand forest allocated more carbon to fine roots than the clay loam forest with the production in loamy sand forest twice (mean \pm standard error $=2.98 \pm 0.36$ and $3.33 \pm 0.69 \mathrm{Mg} \mathrm{Cha}^{-1} \mathrm{yr}^{-1}$, method 1 and 2 , respectively) as much as for the more fertile loamy soil forest $(1.51 \pm 0.14$, method 1 , and from $1.03 \pm 0.31$ to $1.36 \pm 0.23 \mathrm{MgCha}^{-1} \mathrm{yr}^{-1}$, method 2). Similarly, the average of standing crop fine root mass was higher in the white-sands forest $\left(10.94 \pm 0.33 \mathrm{MgCha}^{-1}\right)$ as compared to the forest on the more fertile soil (from $3.04 \pm 0.15$ to $3.64 \pm 0.18 \mathrm{MgCha}^{-1}$ ). The standing crop fine root mass also showed a temporal pattern related to rainfall, with the
\end{abstract}

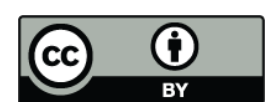

Correspondence to: E. M. Jiménez (emjimenez@unal.edu.co) production of fine roots decreasing substantially in the dry period of the year 2005. These results suggest that soil resources may play an important role in patterns of carbon allocation to the production of fine roots in these forests as the proportion of carbon allocated to above- and below-ground organs is different between forest types. Thus, a trade-off between above- and below-ground growth seems to exist with our results also suggesting that there are no differences in total net primary productivity between these two forests, but with higher below-ground production and lower aboveground production for the forest on the nutrient poor soil.

\section{Introduction}

Tropical forests play a central role in the global carbon cycle (Dixon et al., 1994; Vogt et al., 1996; Brown, 2002), and this has encouraged a long ongoing interest in the study of various components of their net primary productivity, NPP (Clark et al., 2001a; Vogt et al., 1996; Malhi et al., 2004). However, understanding of NPP in many ecosystems, including tropical forests, is still poor due to the scarcity of information on several of its components, especially in the belowground component.

Moreover, fine root dynamics have usually not been measured despite their importance for the plant carbon economy and overall ecosystem functioning. Excluding the belowground portion of NPP could produce significant biases in the quantification of carbon fluxes in ecosystems (Woodward and Osborne, 2000). For example, it has been estimated that about 0.33 of annual global NPP is used to produce fine roots (Jackson et al., 1997).

Published by Copernicus Publications on behalf of the European Geosciences Union. 


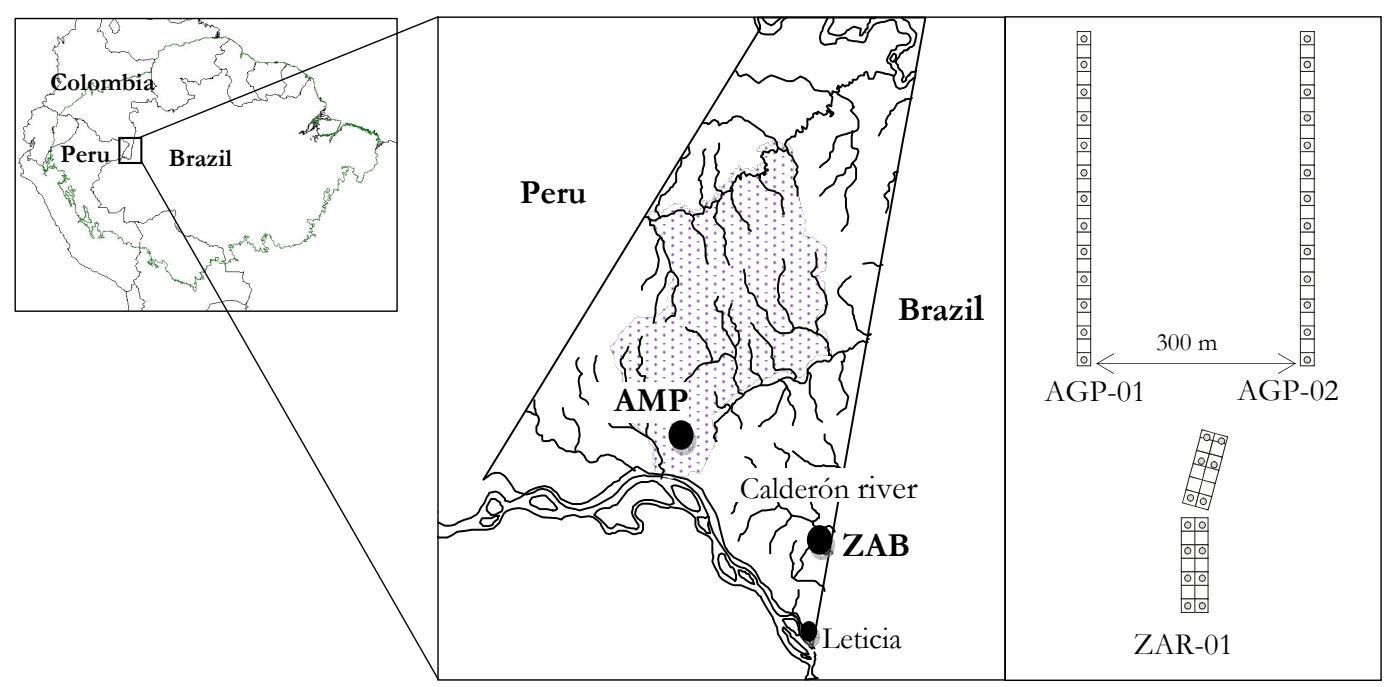

Fig. 1. Localization of the study sites in the Colombian Amazon (Trapecio Amazónico, Leticia): Amacayacu National Natural Park (AMP) with two 1-ha plots: AGP-01 and AGP-02, and Biological Station Zafire (ZAB) with one 1-ha plot: ZAR-01, in the Forest Reservation of the Calderón river. The circles show the areas to sampling fine roots.

Fine root dynamics are particularly important for tropical forests, where biomass and rates of production and decomposition of fine roots are high (Silver et al., 2005). The apparent paradox of the exuberance and large size of tropical humid forests growing on intensively leached soils, suggests that fine roots play an important role in optimizing nutrient acquisition and maintaining a closed nutrient cycle in these forests (Gower, 1987). However, understanding the dynamics of biomass and the factors controlling fine root productivity in tropical forests, including in Amazonia, remains poor (Vogt et al., 1998; Clark et al., 2001b; Silver et al., 2005; Trumbore et al. 2006, Metcalfe et al., 2007, 2008; Aragão et al., 2009).

Hendricks et al. (1993) summarize two contrasting hypotheses proposed to explain the control of soil resources on carbon allocation and NPP. The first one is called the "differential allocation hypothesis", and states that total NPP increases with the increase in the availability of resources, and that allocation between above- and below-ground components is differential, with a higher allocation to foliage and wood than to fine roots on richer sites (Gower et al., 1992; Albaugh et al., 1998). The other hypothesis is the "constant allocation hypothesis", also proposes an increase in total NPP with the increase in the availability of soil resources, but the relative allocation of NPP to above- and below-ground organs remaining relatively constant (Aber et al., 1985; Nadelhoffer et al., 1985; Raich and Nadelhoffer, 1989).

This study evaluates below-ground productivity (fine roots $\leq 2 \mathrm{~mm}$ ) in two mature forests of Terra firme developing on contrasting soils in the Colombian Amazon. The soil underneath one forest was a relatively fertile Plinthosol with loam clay texture and a higher nutrient content than a nearby loamy sand textured Podzol. In particular, we aimed to answer the following questions: (1) How different are the standing crop fine root mass and production between these forest types? (2) How do these variables change with soil depth $(0-10$ and $10-20 \mathrm{~cm})$ in each forest and between them? (3) Is there any temporal variation in the standing crop fine roots mass? And if so, is it related variations in precipitation? As the period of data collection in 2005 occurred an unusually strong dry period, we added one more question: (4) Did the Amazon drought of 2005 affect the production of fine roots at our sites? To answer these questions, we estimated the standing crop fine root mass (SFR), production (FRP), the relative growth rates (RGR) and the turnover rates of fine roots.

This study is orientated by the differential allocation hypothesis, which has been one of the most accepted for tropical forests (Albaugh et al., 1998; Gower et al., 1992; Keyes and Grier, 1981). As a consequence, we predicted a decrease of standing crop fine root mass and production with the increase of soil resources (review in Hendricks et al., 1993). We also predicted that the pattern of FRP would be the opposite to results obtained for wood production by Malhi et al. (2004). They found a positive relationship between wood productivity and soil fertility in the Amazonian basin.

\section{Material and methods}

\subsection{Study sites}

Three 1 ha old-growth forest plots were used to study fine roots in the Colombian Amazon (Trapecio 
Table 1. Main characteristics of the study sites (Colombian Amazon): Amacayacu National Natural Park (AMP) and Biological Station Zafire (ZAB).

\begin{tabular}{|c|c|c|c|}
\hline Characteristics & \multicolumn{2}{|c|}{ AMP } & $\mathrm{ZAB}$ \\
\hline Principal Investigator & \multicolumn{2}{|c|}{ A. Rudas and A. Prieto } & M. C.Peñuela and E. Álvarez \\
\hline Plot Code ${ }^{\mathrm{a}}$ & AGP-01 & AGP-02 & ZAR-01 \\
\hline Latitude & -3.72 & -3.72 & -4.01 \\
\hline Longitude & -70.31 & -70.30 & -69.91 \\
\hline Altitude (m) & 105 & 110 & 130 \\
\hline Forest type & \multicolumn{2}{|c|}{ Terra firme } & Caatinga \\
\hline Soil type ${ }^{b}$ & \multicolumn{2}{|c|}{$\begin{array}{l}\text { Endostagnic Plinthosol } \\
\text { (Alumic, Hyperdystric) - } \\
\text { clay loam }\end{array}$} & $\begin{array}{c}\text { Orteinic Podzol (Oxyaquic) - } \\
\text { loamy sand }\end{array}$ \\
\hline \multicolumn{4}{|c|}{ Chemical properties $(\text { depth } 0-30 \mathrm{~cm})^{\mathrm{c}}$} \\
\hline $\mathrm{pH}$ & 4.50 & 4.29 & 4.27 \\
\hline Resin extractable $\mathrm{P}\left(\mathrm{mg} \mathrm{kg}^{-1}\right)$ & 1 & 1 & 12 \\
\hline Total extractable $\mathrm{P}\left(\mathrm{mg} \mathrm{kg}^{-1}\right)$ & 131 & 123 & 22 \\
\hline Mean N $(\%)$ & 0.15 & 0.16 & 0.11 \\
\hline Mean C (\%) & 1.2 & 1.4 & 2.4 \\
\hline $\mathrm{C} / \mathrm{N}$ & 8 & 8 & 27 \\
\hline $\mathrm{Ca}\left(\mathrm{mmol}_{c} \mathrm{~kg}^{-1}\right)$ & 6 & 5 & 3 \\
\hline $\operatorname{Mg}\left(\mathrm{mmol}_{C} \mathrm{~kg}^{-1}\right)$ & 3 & 3 & 2 \\
\hline $\mathrm{K}\left(\mathrm{mmol}_{c} \mathrm{~kg}^{-1}\right)$ & 1 & 1 & 1 \\
\hline $\mathrm{Na}\left(\mathrm{mmol}_{c} \mathrm{~kg}^{-1}\right)$ & 0 & 0 & 1 \\
\hline $\mathrm{Al}\left(\mathrm{mmol}_{c} \mathrm{~kg}^{-1}\right)$ & 52 & 52 & 1 \\
\hline $\mathrm{SB}\left(\mathrm{mmol}_{C} \mathrm{~kg}^{-1}\right)$ & 10 & 10 & 6 \\
\hline $\mathrm{CIC}\left(\mathrm{mmol}_{C} \mathrm{~kg}^{-1}\right)$ & 6.21 & 6.26 & 0.71 \\
\hline Al Saturation $(\%)$ & 84 & 84 & 10 \\
\hline Base saturation (\%) & 16 & 16 & 90 \\
\hline \multicolumn{4}{|l|}{ Physical properties ${ }^{\mathrm{c}}$} \\
\hline Sand $(\%)$ & 21 & 19 & 75 \\
\hline Clay (\%) & 42 & 43 & 1 \\
\hline Silt $(\%)$ & 37 & 38 & 25 \\
\hline Main root depth $(\mathrm{cm})$ & 20 & 20 & 10 \\
\hline Total root depth $(\mathrm{cm})$ & 50 & 50 & 100 \\
\hline \multicolumn{4}{|c|}{ Available water capacity, $\mathrm{cm}$ water per $\mathrm{cm}$ depth } \\
\hline $0-30 \mathrm{~cm}$ & 3.75 & 3.51 & 2.82 \\
\hline \multicolumn{4}{|l|}{ Vegetation $^{\mathrm{d}}$} \\
\hline Richness (species ha ${ }^{-1}$ ) & 225 & 244 & 25 \\
\hline Mean height of crown (m) & 30 & 30 & 20 \\
\hline Mean stem diameter $(\mathrm{cm})$ & 17.3 & 21 & 15 \\
\hline Stem density $\left(\mathrm{ha}^{-1}\right)$ & 647 & 606 & 866 \\
\hline above-ground biomass $\left(\mathrm{Mg} \mathrm{ha}^{-1}\right)$ & 281 & 276 & 161 \\
\hline
\end{tabular}

a Codes follow those published in Patiño et al. (2009). b World Reference Base for Soil Resources (2006). ${ }^{c}$ Quesada et al. (2009b). d RAINFOR (http://www.rainfor.org). 


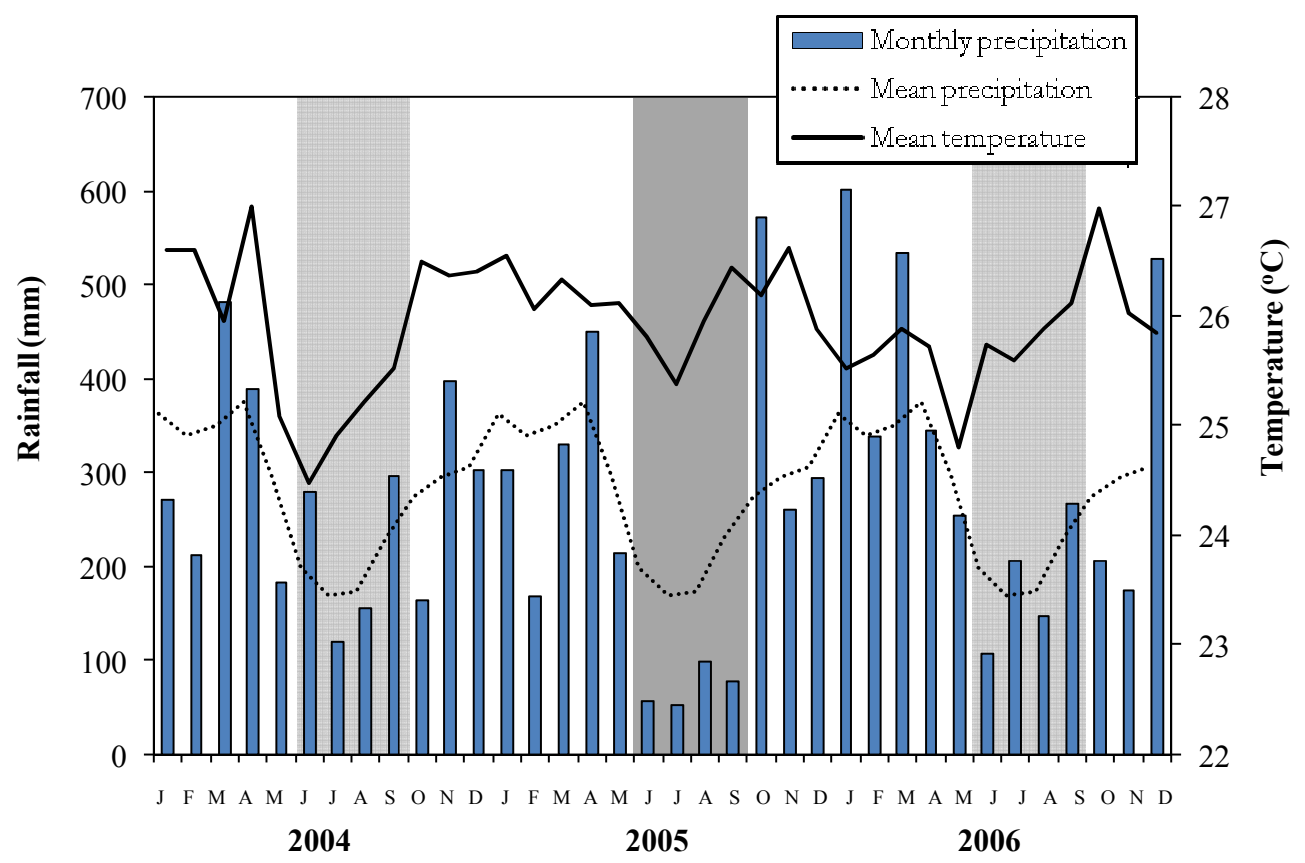

Fig. 2. Patterns of monthly and mean monthly precipitation (1973-2006) and mean temperature from the meteorological station of the Vásquez Cobo airport, Leticia (Amazonas, Colombia) during the time of the research. Shady areas show the dry period of each year, the dark one represents the drought periods. Mean monthly precipitation is plotted repeatedly for every year.

Amazónico) (Fig. 1, Table 1) between September 2004 and December 2006. Two plots, AGP-01 and AGP-02 were sampled in Amacayacu Natural National Park (AMP) as part of the RAINFOR-NPP project (www.rainfor.org). One plot, ZAR-01 was sampled at the Zafire Biological Station (ZAB), Calderón River Forest Preserve as part of Grupo de Ecología de Ecosistemas Terrestres Tropicales Net Primary Productivity Project (http://www.imani.unal.edu.co/).

In general, the Trapecio Amazónico shows a mean monthly rainfall of $278 \mathrm{~mm}$ with a drier period from June to September (mean monthly rainfall of $190 \mathrm{~mm}$ ), and a rainy season from October to May (mean monthly rainfall of $324 \mathrm{~mm}$ ) (data from the Vásquez Cobo airport of Leticia for the period 1973-2006). Mean temperature is about $26^{\circ} \mathrm{C}$ and does not fluctuate greatly through the year (Fig. 2). Relative humidity is high, with a yearly average of $86 \%$. In 2005 , in the middle of the measurements described here, an extended and unusually dry period occurred from June to September ("the 2005 Amazon drought" see for example Phillips et al., 2009). The rainfall in 2005 was thus only $2873 \mathrm{~mm}$, substantially lower than the previous and subsequent year (3250 in 2004 and 3710 in 2006), and than the multi-annual average (3335 mm).

AMP belongs to the geologic unit named Pebas or Solimoes Formation; the terrain is slightly undulated and uniform, with soils moderately deep, well drained, and strongly acidic with moderately fine textures (Herrera, 1997). Soils from ZAB belong to the Terciario Superior Amazónico unit
(Herrera, 1997; PRORADAM, 1979), probably originating from the Guiana Shield (Hoorn, 1994, 2006), and composed mainly by quartz. The terrain is flat and uniform.

Vertical profiles in exchangeable cations, carbon density and particle size distribution have been illustrated for the soils two of the three plots sampled here (AGP-02 and ZAR01) by Quesada et al. (2009b) with the physical and chemical nature of these soils also specifically discussed in that paper. Of particular note is the presence in ZAR-01, classified according to the World Reference Base (2006) as an Ortseinic Podzol (Oxyaquic) of a layer at approximately $1 \mathrm{~m}$ deep in which aluminium concentration increases abruptly as does carbon and to some extent clay content. This reflects the composition of the defining ortseinic layer where Al-humus chelates act as cementing substances and despite the sandy nature of the soil above, can be regarded as a form of "hardpan" both limiting root distribution and impeding drainage. On the other hand, although both AGP-01 and AGP-02 were classified in Quesada et al. (2009b) as being an Endostagnic Plinthosol (Alumic, Hyperdystric), the plinthic layer was considered relatively permeable exerting only moderate constraints on drainage (Quesada et al., 2009a). Data from Table 1 clearly show that AGP-01 and AGP-02 are more fertile than ZAR-01, especially in terms of "total exchangeable phosphorus", a measure as defined by Quesada et al. (2009a) and also being shown by Quesada et al. (2009c) to be one of the best indicators of Amazon soil fertility because of its dominating influence on above-ground wood productivity. 


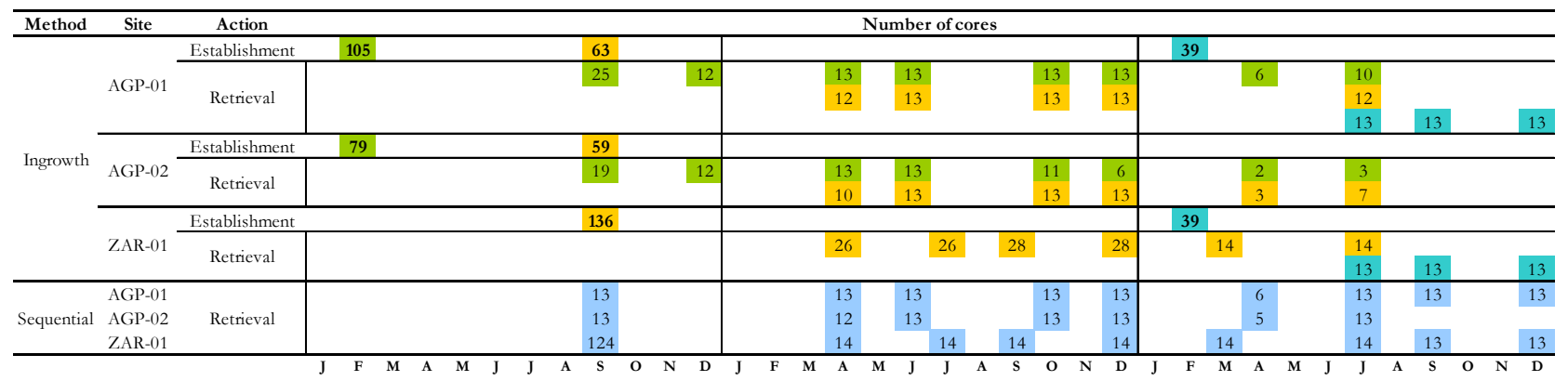

Fig. 3. Schematic representation of the time table for establishment and retrieval of fine root cores. Each colour indicates the establishment of a given set of cores and their correspondent retrieval sequence considering only the $0-20 \mathrm{~cm}$ depth soil core. Note that for sequential cores there is only retrieval (blue).

\subsection{Sampling design}

\subsubsection{The AMP sampling design}

AGP-01 and AGP-02 are two $20 \times 500 \mathrm{~m}$ plots. We selected 13 areas every $40 \mathrm{~m}$ along the plots (Fig. 1). Ingrowth cores were established on three dates: (1) February 2004, (2) September 2004, and (3) February 2006 (Fig. 3). Ingrowth cores were located $1-2 \mathrm{~m}$ from trees $\geq 10 \mathrm{~cm}$ in diameter at breast height $(\mathrm{DBH})$ to avoid coarse roots next to trees; cores were also $0.20-1 \mathrm{~m}$ apart from each other.

\subsubsection{The ZAB sampling design}

ZAR-01 is a plot composed of two rectangular blocks of $40 \times 140 \mathrm{~m}$ and $40 \times 130 \mathrm{~m}$ (Fig. 1). We established ingrowth cores in 14 areas (following the same criteria as for AMP).

\subsection{Core methods}

\subsubsection{Ingrowth cores}

In AMP soil cores were extracted using a root auger $8 \mathrm{~cm}$ diameter and $20 \mathrm{~cm}$-length; in ZAB we used a soil core sampler $5 \mathrm{~cm}$-diameter and $15 \mathrm{~cm}$-length. Differences in core size between sites occurred because the two sampling programs started as independent research projects. Soil cores at both sites were $20 \mathrm{~cm}$ long. Once extracted from the ground cores were divided into two parts: from $0-10 \mathrm{~cm}$ and from $10-20 \mathrm{~cm}$ depth. The soil from each part was sieved twice (through 6 and $1 \mathrm{~mm}$ mesh size, respectively), and all roots and fragments were extracted by hand using forceps. Finally, this root-free soil was sown back in the same hole and depth level of the original sample. In this method only a portion of the initially installed cores were retrieved each sampling date, so the total amount of time that the cores were in the ground increased with each successive sampling.

\subsubsection{Sequential cores}

In the same areas where ingrowth cores were planted we collected undisturbed cores whenever ingrowth cores were planted and extracted (Fig. 3). Handling and processing of samples was the same as described for ingrowth cores.

\subsection{Fine root extraction}

In all cases, the first collection of ingrowth cores was done 5-7 months after establishment; subsequent collections were done at 2-4 month intervals (Fig. 3). Selection of the time interval for the first collection was based on reports of mean fine roots life time for several tropical forests, which ranges from 6 to 12 months (Priess et al., 1999), previous studies having shown that starting collection after a shorter period than this is too early to allow representative root growth into the root-free soil cores.

After extraction, soil cores were packed in labelled polythene bags and transported to field stations where they were washed and sorted in nearby streams. Samples were then airdried before transportation to the laboratory, where they were washed with deionised water, sieved (mesh size $0.1 \mathrm{~mm}$ ), and remaining roots manually extracted with forceps. Roots were packed in paper bags and oven-dried for $24 \mathrm{~h}$ at $80^{\circ} \mathrm{C}$, and then weighed ( $0.001 \mathrm{~g}$ precision).

\subsection{Statistical methods}

Tests for differences between forest types, time and soil depths were carried out with one way ANOVA. Data had been previously checked for normality of distributions with the Kolmogorov-Smirnov and Shapiro-Wilk tests and, for homogeneity of variances with the test of Levene (Dytham, $2003)$. When ANOVA was significant $(p<0.05)$, we used the post hoc test of Tukey to compare means. When the requirements of ANOVA were not met, we used non-parametrical tests, such as the test of Kruskal-Wallis followed by the test $\mathrm{U}$ of Mann-Whitney between pairs of data until the differences of the entire group were evaluated. Statistical analyses 
were done with the software SPSS 11.5.0 (6 September 2002, LEAD Technologies, Inc).

FRP $\left(\mathrm{Mg} \mathrm{ha}^{-1} \mathrm{yr}^{-1}\right)$ was calculated as the time between ingrowth core installation (time zero) and the subsequent 610 months, scaled to a yearly basis (Vogt et al., 1998). In this way, for the first establishment in the loamy soil forest, calculation of yearly production was based on growth between February and December 2004; for the establishment 2, on growth between September 2004 and April 2005; and for the loamy sand forest, on growth between September 2004 and July 2005; for the establishment 3 in both forest types, production was based on growth between February and December 2006.

To compare FRP in standard units between forests and time intervals, we calculated the relative growth rate (RGR), defined by Fogg (1967) and Kozlowski et al. (1991) as:

$\mathrm{RGR}=\frac{\log \left(W_{1}\right)-\log \left(W_{0}\right)}{t}$

where, log represents the natural logarithm; $W_{1}$ and $W_{0}$ are the final and initial dry weight of fine roots, respectively and $t$ is the time between the two collections in days.

Due to the occurrence of a strong drought period in the middle of our sampling in 2005 (Fig. 2), we tested for its effect on root production through the comparison of RGR before (September-December 2004), during (April-July 2005), and after drought (September-December 2006). For the loamy sand forest, we also analysed the RGR in the time interval between the installation and the harvest 370 days later, and between measurements separated by 89 days, this being with the purpose of having an estimate of RGR during drought, between July and September 2005. We considered for the estimation of RGR the time elapsed between the establishment and the retrieval time of cores, trying to compare similar periods of growth.

Annual production of fine roots $\left(\mathrm{Mg} \mathrm{ha}^{-1} \mathrm{yr}^{-1}\right)$ was also estimated from the data of sequential cores as the difference between maximum and minimum biomass measured in one year (Vogt et al., 1998). To analyse the same time intervals for all plots, even though the length of monitoring was different, we selected two 12 month periods (April 2005-2006 and December 2005-2006) for this analysis. The initial period, from September 2004 to April 2005 was not used for calculations because the sharp seasonality of SFR observed in the clay loam soil forest during this period could introduce biases in the estimations.

Turnover rate was calculated as the FRP divided into the average SFR for that year; carbon content in fine roots was assumed to be equal to $50 \%$ of dry mass (Silver et al., 2005).

To evaluate the association between SFR $\left(\mathrm{Mgha}^{-1}\right)$ from data of sequential cores- and mean daily rainfall $(\mathrm{mm}$ day $^{-1}$ ), we used the Spearman's correlation coefficient, $r_{S}$ (Dytham, 2003).

Several works have correlated the production and the standing crop fine roots mass with rainfall (Gower et al.,
1992; Kavanagh and Kellman, 1992; Vogt et al., 1998; Yavitt and Wright, 2001). However, the speed of the response and its temporal scale is unknown. It is presumed that this response can be variable depending on soil conditions and rainfall regimes (Yavitt and Wright, 2001). For this reason, we explored a wide range of time intervals with respect to rainfall, examining the average daily rainfall of the previous 7 , $15,30,60,90,100$, and 120 days before the sampling day. We also explored the existence of a lagged response of SFR to rainfall; for this purpose we considered the average daily rainfall for fixed time periods of $15,30,60$, and 90 days with time lags of $7,15,30,120$, and 150 days from the sampling date.

\section{Results}

In total we collected 207, 138, and 175 cores from AGP01 and AGP-02 and ZAR-01 respectively with the ingrowth cores method and 110 and 82 soil cores during the monitoring period from AGP-01 and AGP-02 respectively and with 234 samples from ZAR-01 with the sequential core. Figure 3 shows details of the establishment and retrieval timetable for the two methods and plots.

\subsection{Standing crop fine root mass and production from ingrowth cores}

The standing crop for each collection date and soil depth (0$10,10-20$, and $0-20 \mathrm{~cm}$ ) did not show significant differences $(p>0.05)$ between the two clay loam soil plots (AGP-01 and AGP-02). For this reason, these plots were considered as a unique site in subsequent analyses and were significantly different $(p<0.05)$ from the loamy sand forest plot (ZAR$01)$.

SFR and FRP were higher in the $0-10 \mathrm{~cm}$ than in the 0-20 cm soil depth for all establishment dates and forests (Fig. 4 and Table 2). SFR in the clay loam soil forest showed significant differences $(p<0.05)$ between soil depths $(0-10 \mathrm{~cm}$ and $10-20 \mathrm{~cm})$ in most collection times and establishment dates, the exception being the collection of April 2005 for the second establishment. Similarly, in the loamy sand forest, SFR showed significant differences between soil depths in most collection dates, but differences between depths were not significant for the first collection dates.

Figures of FRP were higher in the forest on loamy sand forest than in the clay loam forest in all depths and establishment dates (Table 2). Differences of FRP in the $0-20 \mathrm{~cm}$ layer were significant $(p<0.05)$ in establishments 2 and 3 ; however, in establishment 2 differences between forest types were not significant $(p>0.05)$ when evaluated independently at each soil depth $(0-10 \mathrm{~cm}$ and $10-20 \mathrm{~cm})$. In establishment 3 , we found significant differences $(p<0.05)$ of FRP between forest types at all soil depths. Results for SFR had similar trends: establishments 2 and 3 showed significant 


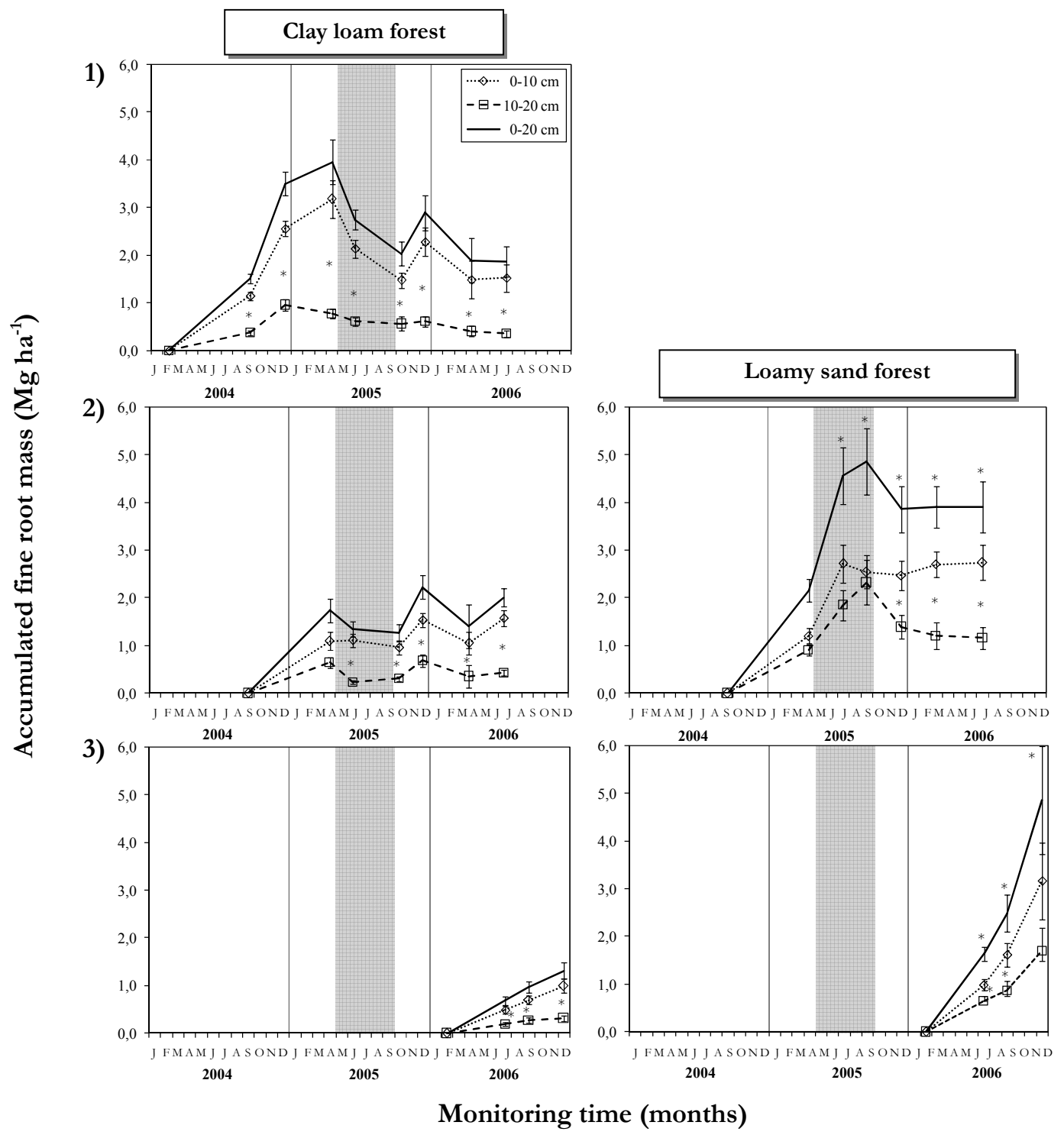

Fig. 4. Fine root production $\left(\mathrm{Mg} \mathrm{ha}^{-1}\right)$ in the first $20 \mathrm{~cm}$ of soil depth estimated by the ingrowth core method in two forests with different soil types in the Colombian Amazon. Cores were established in three times: (1) February of 2004, (2) September of 2004 and, (3) February of 2006. Values are the means and the standard errors. The shady area is the drought period of the year 2005 . ${ }^{*}$ Significant differences $(p<0.05)$ of fine root mass in relation to: (1) differences between soil depths $(0-10 \mathrm{~cm}$ and $10-20 \mathrm{~cm})$ per collection date in each plot, $(2)$ differences between all soil depths per collection date and forest type.

differences $(p<0.05)$ between the two forest types at each soil depth in most dates of collection, the except being for establishment 2 in April 2005 for which differences were not significant between sites at any soil depth, and in April 2006 at the $10-20 \mathrm{~cm}$ depth. Nevertheless, for this collection date, the other depths $(0-10 \mathrm{~cm}$ and $0-20 \mathrm{~cm})$ showed significant differences $(p<0.05)$ between the two forests.
The rates of FRP in the first $20 \mathrm{~cm}$ of soil ranged from $1.60 \mathrm{Mg} \mathrm{ha}^{-1} \mathrm{yr}^{-1}$ in the forest growing on the clay loam soil to $6.00 \mathrm{Mg} \mathrm{ha}^{-1} \mathrm{yr}^{-1}$ on sandy soil, both rates obtained for establishment 3 (Table 2). Likewise, mean FRP was lower for the clay loam forest $\left(3.02 \mathrm{Mg} \mathrm{ha}^{-1} \mathrm{yr}^{-1}\right)$ than in the loamy sand forest with an estimate of $5.97 \mathrm{Mg} \mathrm{ha}^{-1} \mathrm{yr}^{-1}$ being obtained (Table 2).

Relative growth rates (RGR) for the three periods evaluated were higher for the loamy sand forest than for the clay loam forest (Fig. 5). RGR in the clay loam forest both before and after drought were also higher than during drought in 
Table 2. Fine root production $\left(\mathrm{Mg} \mathrm{ha}^{-1} \mathrm{yr}^{-1}\right)$ in the first $20 \mathrm{~cm}$ of soil depth in two forests with different soil types in the Colombian Amazon, estimated from ingrowth cores established in three times: (1) February of 2004, (2) September of 2004 and, (3) February of 2006.

\begin{tabular}{|c|c|c|c|c|}
\hline \multirow{2}{*}{ Soil depth } & \multicolumn{2}{|c|}{ Clay loam forest } & \multicolumn{2}{|c|}{ Loamy sand forest } \\
\hline & $\mathrm{N}$ & Mean & $\mathrm{N}$ & Mean \\
\hline \multicolumn{5}{|c|}{ Establishment 1 ( 0.83 years) } \\
\hline $0-10 \mathrm{~cm}$ & 24 & $3.082(0.196)$ & - & - \\
\hline $10-20 \mathrm{~cm}$ & 25 & $1.153(0.144)$ & - & - \\
\hline $0-20 \mathrm{~cm}$ & 24 & $4.215(0.307)$ & - & - \\
\hline Total C & & 2.108 & & \\
\hline \multicolumn{5}{|c|}{ Establishment 2 ( 0.52 and 0.77 years, respectively) } \\
\hline $0-10 \mathrm{~cm}$ & 22 & $2.104(0.357) \mathrm{a}$ & 26 & $3.530(0.520) \mathrm{a}$ \\
\hline $10-20 \mathrm{~cm}$ & 22 & $1.243(0.212) \mathrm{a}$ & 26 & $2.404(0.414) \mathrm{a}$ \\
\hline $0-20 \mathrm{~cm}$ & 22 & $3.346(0.472) \mathrm{a}$ & 26 & $5.934(0.773) b$ \\
\hline Total C & & 1.680 & & 2.967 \\
\hline \multicolumn{5}{|c|}{ Establishment 3 ( 0.82 and 0.81 years, respectively) } \\
\hline $0-10 \mathrm{~cm}$ & 13 & $1.210(0.178) \mathrm{a}$ & 13 & $3.910(0.990) b$ \\
\hline $10-20 \mathrm{~cm}$ & 13 & $0.390(0.078) \mathrm{a}$ & 13 & $2.091(0.589) b$ \\
\hline $0-20 \mathrm{~cm}$ & 13 & $1.600(0.203) \mathrm{a}$ & 13 & $6.001(1.388) b$ \\
\hline Total C & & 0.800 & & 3.001 \\
\hline \multicolumn{5}{|l|}{ Mean } \\
\hline $0-20 \mathrm{~cm}$ & & $3.022(0.279) \mathrm{a}$ & & $5.968(0.721) b$ \\
\hline Total C & & $1.511(0.140)$ & & $2.984(0.361)$ \\
\hline
\end{tabular}

In parenthesis the time elapsed between the establishment and the retrieve of cores. Standard errors in parenthesis. Different letters show significant differences $(p<0.05)$ in the production between forests.

2005. Before the drought RGR was $4.47 \mathrm{yr}^{-1}$ and $3.94 \mathrm{yr}^{-1}$ for AGP-01 and AGP-02, respectively, and after drought it was $1.21 \mathrm{yr}^{-1}$ for AGP-01. RGR during the drought period were lower: -1.00 and $-0.72 \mathrm{yr}^{-1}$ for AGP-01 and AGP02 , respectively. RGR before and after drought in the loamy sand forest were similar: 2.94 and $2.08 \mathrm{yr}^{-1}$, respectively, while the RGR estimated during the final part of the drought period were much lower $\left(-0.77 \mathrm{yr}^{-1}\right)$, similar to those obtained for the forest on clay loam soil.

\subsection{Standing crop fine root mass, production, and turnover rates from sequential soil coring}

Similar to results obtained for the ingrowth cores, SFR was significantly higher $(p<0.05)$ at $0-10 \mathrm{~cm}$ depth than at 10 $20 \mathrm{~cm}$ (Fig. 5 and Table 3). Temporal variation of SFR along the monitoring period also showed significant differences among collection dates for all plots: AGP-01 $\left(F_{8,101}=4.754\right.$, $p<0.01)$, AGP-02 $\left(X^{2}=23.130, D . F .=6, p=0.001\right)$, and ZAR-01 $\left(X^{2}=49.258, D . F .=8, p=0.000\right)$ (Fig. 6). December 2005 had the highest value of SFR $\left(5.04 \mathrm{Mg} \mathrm{ha}^{-1}\right)$ in AGP-01. In AGP-02 September 2004, April and December 2005 showed higher values $\left(3.90,4.27\right.$ and $5.04 \mathrm{Mg} \mathrm{ha}^{-1}$, respectively) whereas July 2006 showed the lowest value (2.44 Mg ha-1). For ZAR-01, September 2004, July 2005, and December 2006, showed significant differences (Fig. 6). In the clay loam forest (plots AGP-01 and AGP-02) the standing crop increased between September and December, while for the loamy sand forest the increase occurred between March and July.

The standing crop also showed significant differences between plots $(p<0.05)$ at each collection date and at all soil depths $(0-10,10-20$ and $0-20 \mathrm{~cm})$, but differences between plots of clay loam forest (AGP-01 and AGP-02) were not significant $(p>0.05)$ for most sampling dates (Fig. 7), the exception being April 2005. The loamy sand forest (ZAR-01) showed values significantly higher $(p<0.05)$ than the plots on clay loam soil for almost all collection dates.

By contrast, SFR measured for the entire monitoring time (2.2 years) showed significant differences $(p<0.05)$ between plots at all soil depths considered (Table 3 ). The average SFR for over the monitoring period was almost three times higher in the loamy sand forest plot than in plots of clay loam forest (10.94 Mg ha ${ }^{-1}$ in ZAR-01 and 3.04 and $3.64 \mathrm{Mg} \mathrm{ha}^{-1}$ for AGP-01 and AGP-02, respectively). Likewise, when the two years were evaluated independently, SFR was higher in the loamy sand forest $\left(8.92\right.$ and $4.41 \mathrm{Mg} \mathrm{ha}^{-1} \mathrm{yr}^{-1}$ for years 1 and 2, respectively) than in the clay loam forest (for AGP-01: 2.77 and $2.67 \mathrm{Mg} \mathrm{ha}^{-1} \mathrm{yr}^{-1}$ for years 1 and 2, respectively, and $2.05 \mathrm{Mg} \mathrm{ha}^{-1} \mathrm{yr}^{-1}$ for AGP-02 in year 1) (Table 3). 


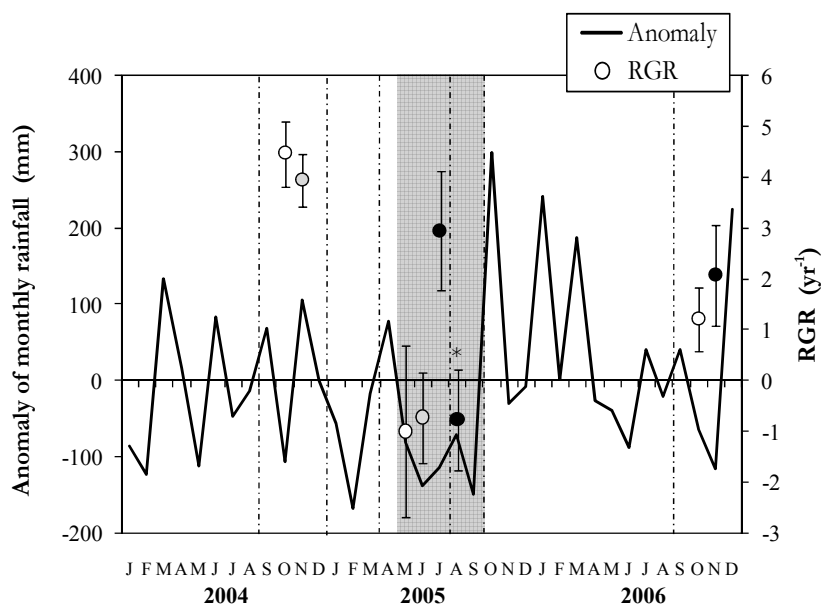

Fig. 5. Anomaly of rainfall along the period of study, calculated as the precipitation of each month minus the mean monthly precipitation (1973-2006) and relative growth rates (RGR) of fine root mass $\left(\mathrm{yr}^{-1}\right)$ for the forests studied. Dotted vertical lines show the time intervals considered for the estimation of RGR from ingrowth cores; the portion dashed shows the drought of 2005. Circles with vertical bars represent the mean and standard errors of RGR; white and gray circles for plots on clay loam forest (AGP-01 and AGP02 , respectively) and black circles for the plot on loamy sands forest (ZAR-01). ${ }^{*}$ RGR for ZAR-01, calculated between the former harvest (July 2005) and the following harvest (September 2005).

Turnover rates $\left(\mathrm{yr}^{-1}\right)$ estimated from sequential cores for each year (Table 3), varied between $0.53-0.84$ in the clay loam forest, and between $0.51-0.81$ in the loamy sand forest. Averages per plot were 0.84 and 0.53 for AGP-01 and AGP02 , and 0.66 for ZAR-01.

\subsection{Relationship between the standing crop fine root mass and rainfall}

We found a significant correlation between SFR and rainfall $\left(\mathrm{mm} \mathrm{day}^{-1}\right)$ in both forest types (Table 6). For plots in the clay loam soil forest (AGP-01 and AGP-02), the correlation was positive and significant between SFR and mean daily rainfall with and without time lag. Rainfall variables that showed a positive correlation ( $R$ between 0.1884 and 0.2397 ) in AGP-01 were average daily rainfall of the previous 90 days, average rainfall of the previous 60 and 90 days with time lags of 7 and 15 days, and average rainfall of the previous 60 days with a time lag of 30 days. In AGP-02 we obtained a higher number of rainfall variables with positive and higher correlations (0.2397-0.4702); variables with significant correlations were average daily rainfall of last 60 , 90, 100 and 120 days, as well as rainfall with time lags of 7 days in all the fixed periods considered $(15,30,60$ and 90 days), rainfall with time lag of 15 days for fixed periods of 30 and 60 days, and rainfall with time lag of 30 days with a fixed period of 15 days. Rainfall with the longest time lags

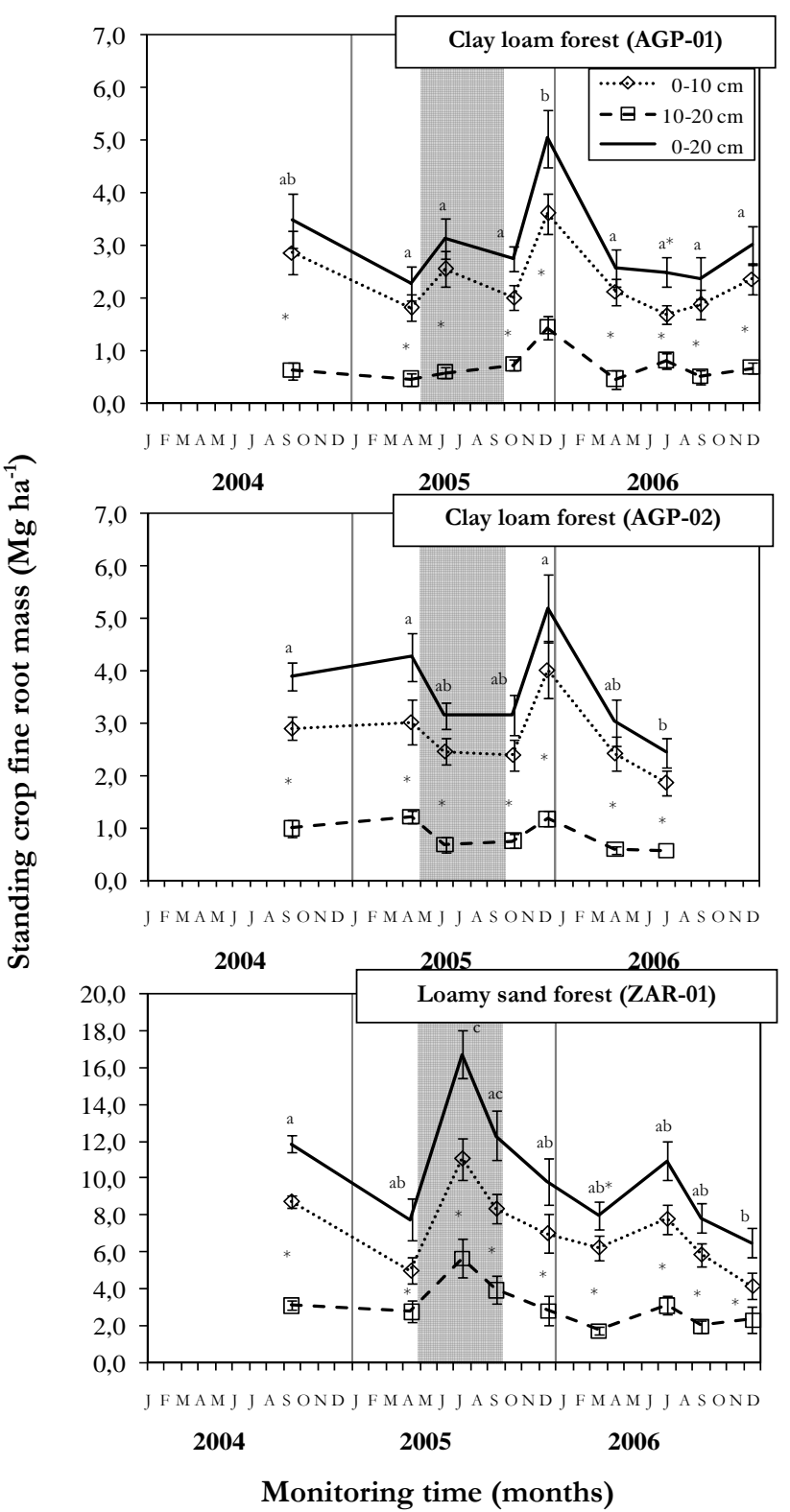

Fig. 6. Temporal variation of fine root mass $\left(\mathrm{Mg} \mathrm{ha}^{-1}\right)$ in the $0-$ $20 \mathrm{~cm}$ soil depth in two forests on different soil types in Colombian Amazon: one forest on clay loam soils (plots AGP-01 and AGP02) and another on loamy sands (plot ZAR-01), estimated with the method of sequential cores. Values are averages and standard deviations. The area dashed shows the drought period in 2005. Different letters in each plot show significant differences $(p<0.05)$ of fine root mass $(0-20 \mathrm{~cm})$ between collection dates. ${ }^{*}$ Significant differences $(p<0.05)$ of fine root mass in each collection date between depths $0-10$ and $10-20 \mathrm{~cm}$.

(120 and 150 days) and almost all fixed periods considered, showed negative correlation with SFR in plots of clay loam forest $(-0.2593$ to -0.3719$)$. 
Table 3. Fine root mass $\left(\mathrm{Mg} \mathrm{ha}^{-1}\right)$, production $\left(\mathrm{Mg} \mathrm{ha}^{-1} \mathrm{yr}^{-1}\right)$, and turnover rates $\left(\mathrm{yr}^{-1}\right)$ in two forests with different soil types in the Colombian Amazon: one forest on clay loam soils (two 1-ha plots: AGP-01 and AGP-02) and other on loamy sands (one 1-ha plot: ZAR01), estimated by the sequential core method.

\begin{tabular}{|c|c|c|c|}
\hline & \multicolumn{2}{|c|}{ Clay loam forest } & \multirow{2}{*}{$\frac{\text { Loamy sand forest }}{\text { ZAR-01 }}$} \\
\hline & AGP-01 & AGP-02 & \\
\hline \multicolumn{4}{|l|}{ Mean mass by soil depth ${ }^{\text {a }}$} \\
\hline $0-10 \mathrm{~cm}$ & $2.331(0.114) \mathrm{a}$ & $2.758(0.148) b$ & $7.861(0.240) \mathrm{c}$ \\
\hline $10-20 \mathrm{~cm}$ & $0.711(0.053) \mathrm{a}$ & $0.879(0.056) \mathrm{b}$ & $3.077(0.174) \mathrm{c}$ \\
\hline $0-20 \mathrm{~cm}$ & $3.043(0.151) \mathrm{a}$ & $3.637(0.181) b$ & $10.938(0.327) \mathrm{c}$ \\
\hline \multicolumn{4}{|l|}{ Mean mass by year $(0-20 \mathrm{~cm})$} \\
\hline April 2005-2006 & $3.30(0.24)$ & $3.85(0.24)$ & $10.94(0.65)$ \\
\hline December 2005-2006 & $3.17(0.23)$ & - & $8.69(0.46)$ \\
\hline \multicolumn{4}{|c|}{ Maximum and minimum values of annual stocks } \\
\hline \multirow[t]{2}{*}{ April 2005-April 2006} & $5.042(0.547)$ & $5.196(0.648)$ & $16.710(1.288)$ \\
\hline & $2.273(0.327)$ & $3.145(0.258)$ & $7.794(1.156)$ \\
\hline \multirow[t]{2}{*}{ December 2005-December 2006} & $5.042(0.547)$ & - & $10.943(1.046)$ \\
\hline & $2.374(0.403)$ & - & $6.530(0.824)$ \\
\hline \multicolumn{4}{|l|}{ Production ${ }^{b}$} \\
\hline April 2005-April 2006 & $2.769(0.546)$ & $2.051(0.621)$ & $8.916(2.102)$ \\
\hline December 2005-December 2006 & $2.668(0.574)$ & - & $4.413(1.256)$ \\
\hline Mean Biomass & $2.719(0.452)$ & $2.051(0.621)$ & $6.665(1.377)$ \\
\hline Mean C & $1.359(0.226)$ & $1.026(0.310)$ & $3.332(0.689)$ \\
\hline \multicolumn{4}{|l|}{ Turnover rates } \\
\hline April 2005-April 2006 & 0.84 & 0.53 & 0.81 \\
\hline December 2005-December 2006 & 0.84 & - & 0.51 \\
\hline Mean & 0.84 & 0.53 & 0.66 \\
\hline
\end{tabular}

Standard errors in parenthesis. ${ }^{a}$ Mean Fine root mass for the whole monitoring time (2.2 years). ${ }^{b}$ Difference between maximum and minimum fine root mass measured during a year.

In the loamy sand forest plot SFR showed negative correlations with daily averages of rainfall of the previous 7,15 , $30,60,90,100$ and 120 days without time lag, and with rainfall for fixed periods of 15, 30 and 60 days with time lags of 7 and 30 days, and finally, with rainfall of the previous 30 days with time lag of 120 days. Contrary to the results in the clay loam soil plots, correlations for long time lags were positive: correlations varied from 0.1657 to 0.1943 for a time lag of 150 days and fixed periods of 30 and 60 days.

\section{Discussion}

\subsection{Carbon allocation to production of fine roots to fine roots}

The forest growing on the Podzol soil had a much higher average of SFR $\left(10.94 \mathrm{Mg} \mathrm{ha}^{-1}\right)$ than the forest on the clay loam textured Plinthosol (3.04 and $3.64 \mathrm{Mgha}^{-1}$ ). This agrees with several reviews, which show that higher values of SFR in tropical forests occur in soils with low nutrient content, such as Caatinga (Cavelier, 1992; Vogt et al., 1996). These results are inside the range reported in the Amazon basin and other similar forests in Venezuela (Table 4), which varied between 2.18 and $39.50 \mathrm{Mg} \mathrm{ha}^{-1}$ for a forest on clays (Acrisols/Ferralsols) in Brazil and a transition between well drained and Caatinga forest (Acrisols/Podzols) in Venezuela, respectively.

Values of SFR reported in Table 4 for forests on Podzols (ranging from 4.98 to $20.00 \mathrm{Mg} \mathrm{ha}^{-1}$ ) are generally higher than those for forests on most Acrisols/Ferralsols (from 2.18 to $3.64 \mathrm{Mg} \mathrm{ha}^{-1}$ ), which were close to the values obtained for forests on the same soil type of this study; however, the value for forests classified by Duivenvoorden and Lips (1995) as belonging to well-drained soils (probably Acrisols/Alisols) in the middle Caquetá (Colombian Amazon) are much higher than this general range $\left(12 \mathrm{Mg} \mathrm{ha}^{-1}\right)$ as estimates for Ferralsol/Acrisol soils in Eastern Brazil taken from data reported by Metcalfe et al. (2008). It is, however, important to note 


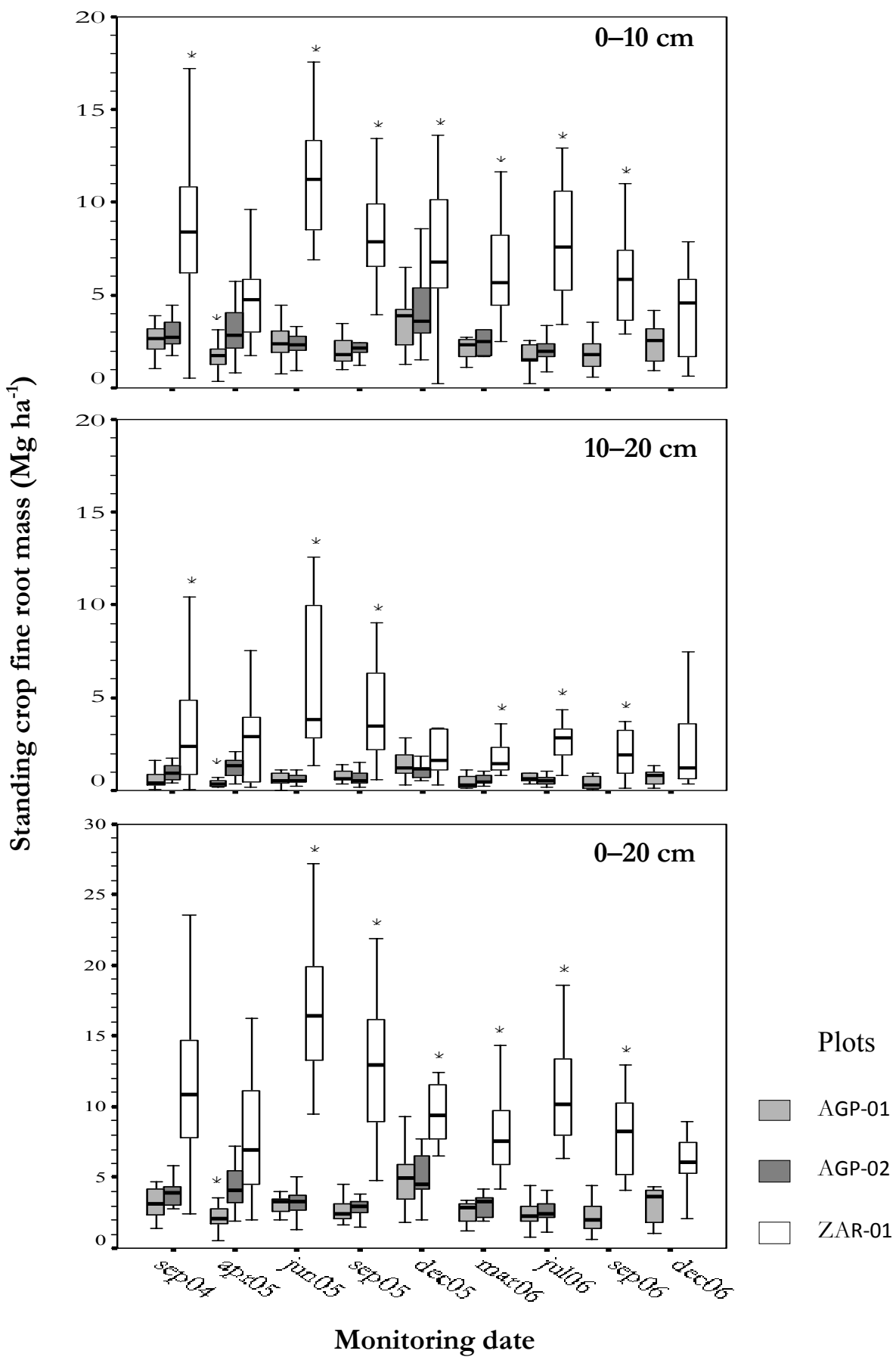

Fig. 7. Fine root mass $\left(\mathrm{Mg} \mathrm{ha}^{-1}\right)$ at soil depths: 0-10, 10-20, and 0-20 cm, in plots of two forests on different soils in Colombian Amazon: one forest on clay loam soil (plots AGP-01 and AGP-02) and other forest on loamy sand (plot ZAR-01), estimated by the sequential core method. *Significant differences $(p<0.05)$ of fine root mass in each collection date among plots.

that even within the one soil group, significant variations in nutrient contents can be observed. For example, Quesada et al. (2009b) found $0-30 \mathrm{~cm}$ total exchangeable phosphorus concentrations to vary from 27 to $68 \mathrm{mg} \mathrm{kg}^{-1}$ across a range of 13 ferralsols sampled as part of a Amazon Basinwide study and to vary from 8 to $91 \mathrm{mg} \mathrm{kg}^{-1}$ for the seven acrisols sampled as part of the same work. It is thus difficult to make generalisations about likely differences in soil fertility based on a simple knowledge of (usually only approximately and often incorrectly identified) soil classifications.

Our estimates of FRP for the loamy sand forest are high compared with the range shown in Table 4 
Table 4. Standing crop fine root mass (SFR), production (FRP) and turnover rates (FRT) of fine roots $(<2 \mathrm{~mm})$ in forests of the Amazon basin.

\begin{tabular}{|c|c|c|c|c|c|}
\hline Forest type & $\begin{array}{r}\text { Soil Depth } \\
(\mathrm{cm})\end{array}$ & $\begin{array}{r}\text { SFR } \\
\left(\mathrm{Mgha}^{-1}\right)\end{array}$ & $\begin{array}{r}\text { FRP } \\
\left(\mathrm{Mg} \mathrm{ha}^{-1} \mathrm{yr}^{-1}\right)\end{array}$ & $\begin{array}{r}\text { FRT } \\
\left(\mathrm{yr}^{-1}\right)\end{array}$ & Reference \\
\hline \multicolumn{6}{|l|}{ Brazil } \\
\hline Campina on humus (Podzol) & 29 & 4.98 & - & - & Klinge (1973) \\
\hline TF Forest (Ferralsol) & 27 & 5.33 & - & - & Klinge (1973) \\
\hline TF Forest (Ferralsol) "clay plot"1 & 30 & - & 11.40 & - & Metcalfe et al. (2007) \\
\hline TF Forest (Ferralsol) "clay plot"1 & 30 & - & 5.00 & - & Metcalfe et al. (2007) \\
\hline TF Forest (Ferralsol) "clay plot"1 & 30 & - & 5.60 & - & Metcalfe et al. (2007) \\
\hline TF Forest (Ferralsol) "clay plot"1 & 30 & - & 2.10 & - & Metcalfe et al. (2007) \\
\hline TF Forest (Acrisol) "sand plot" & 30 & 14.00 & 4.00 & 0.29 & Metcalfe et al. $(2008)^{* *}$ \\
\hline TF Forest (Acrisol) "dry plot" & 30 & 10.00 & 3.00 & 0.30 & Metcalfe et al. $(2008)^{* *}$ \\
\hline TF Forest (Ferralsol) "clay plot" & 30 & 15.00 & 4.00 & 0.27 & Metcalfe et al. $(2008)^{* *}$ \\
\hline TF Forest (Archao-Anthroposol) "fertile plot" & 30 & 11.00 & 7.00 & 0.64 & Metcalfe et al. $(2008)^{* *}$ \\
\hline Forest on clay soils (Ferralsol) - year 1 & 10 & 2.18 & 2.04 & 0.70 & Silver et al. (2005) \\
\hline Forest on clay soils (Ferralsol) - year 2 & 10 & 2.18 & 1.57 & 0.69 & Silver et al. (2005) \\
\hline Forest on sandy loam soils (Acrisol) - year 1 & 10 & 2.92 & 2.54 & 0.57 & Silver et al. (2005) \\
\hline Forest on sandy loam soils (Acrisol) - year 2 & 10 & 2.92 & 1.49 & 0.39 & Silver et al. (2005) \\
\hline Mature forest (Acrisol/Ferralsol) ${ }^{2 \mathrm{a}}$ & 10 & 2.60 & 0.35 & 0.14 & Trumbore et al. (2006) ${ }^{* *}$ \\
\hline Mature forest (Acrisol/Ferralsol) ${ }^{2 b}$ & 10 & 2.60 & 0.92 & 0.35 & Trumbore et al. (2006)** \\
\hline Mature forest (Acrisol/Ferralsol) ${ }^{2 \mathrm{c}}$ & 10 & 2.60 & 1.18 & 0.45 & Trumbore et al. (2006) $)^{* *}$ \\
\hline Mature forest (Acrisol/Ferralsol) $)^{2 \mathrm{~d}}$ & 10 & 2.60 & 0.52 & 0.20 & Trumbore et al. (2006) $)^{* *}$ \\
\hline Secondary forest of 17 years old (Acrisol/Ferralsol) ${ }^{2 \mathrm{~d}}$ & 10 & 3.42 & 0.85 & 0.25 & Trumbore et al. $(2006)^{* *}$ \\
\hline \multicolumn{6}{|l|}{ Colombia } \\
\hline Flooded forest on well drained soils (Cambisol) ${ }^{3 *}$ & 20 & 10.00 & - & - & Duivenvoorden and Lips (1995) \\
\hline TF Forest on well drained soils (Acrisol/Alisol) $)^{3 *}$ & 20 & 12.00 & - & - & Duivenvoorden and Lips (1995) \\
\hline TF Forest on white sands (Podzol) $)^{3 *}$ & 20 & 20.00 & - & - & Duivenvoorden and Lips (1995) \\
\hline Secondary forest of 18 years old in low terraces in the Caquetá river & 20 & 12.82 & - & - & Pavlis and Jeník (2000) \\
\hline Secondary forest of 25 years old in low terraces in the Caquetá river & 20 & 11.24 & - & - & Pavlis and Jeník (2000) \\
\hline Secondary forest of 37 years old in low terraces in the Caquetá river & 20 & 16.87 & - & - & Pavlis and Jeník (2000) \\
\hline Mature forest in low terraces in the Caquetá river & 20 & 30.61 & - & - & Pavlis and Jeník (2000) \\
\hline TF Forest on clay soils (Plinthosol) $)^{4 a}$ & 20 & - & 3.02 & - & Present study \\
\hline TF Forest on white sands/Caatinga (Podzol) ${ }^{4 a}$ & 20 & - & 5.97 & - & Present study \\
\hline TF Forest on clay soils (Plinthosol) ${ }^{4 \mathrm{~b}}$ & 20 & 3.04 & 2.72 & 0.84 & Present study \\
\hline TF Forest on clay soils (Plinthosol) ${ }^{4 b}$ & 20 & 3.64 & 2.05 & 0.53 & Present study \\
\hline TF Forest on white sands/Caatinga (Podzol) $)^{4 b}$ & 20 & 10.94 & 6.67 & 0.66 & Present study \\
\hline \multicolumn{6}{|l|}{ Venezuela $^{5}$} \\
\hline High Caatinga & - & - & 1.20 & - & Cuevas and Medina (1988) \\
\hline TF Forest (Acrisol/Ferralsol)* & - & - & 2.01 & - & Jordan and Escalante (1980) \\
\hline TF Forest (Acrisol/Ferralsol)* & - & - & 11.17 & - & Jordan and Escalante (1980) \\
\hline High forest (Ferralsol) & 20 & 11.40 & 3.12 & 0.27 & Priess et al. (1999)** \\
\hline Medium forest (Ferralsol) & 20 & 12.20 & 3.06 & 0.25 & Priess et al. (1999)** \\
\hline Low forest (Ferralsol) & 20 & 9.63 & 4.20 & 0.44 & Priess et al. (1999)** \\
\hline TF Forest & 30 & 13.80 & - & - & Rev. in Cavelier (1992) \\
\hline Bana & 30 & 15.70 & - & - & Rev. in Cavelier (1992) \\
\hline Transitional forest Caatinga/Bana (Podzol) & 30 & 15.70 & - & - & Rev. in Cavelier (1992) \\
\hline Caatinga & 30 & 17.90 & - & - & Rev. in Cavelier (1992) \\
\hline Transitional forest TF/Caatinga (Podzol) & 30 & 39.50 & - & - & Rev. in Cavelier (1992) \\
\hline TF Forest & 10 & - & 15.4 & - & Rev. in Nadelhoffer and Raich (1992) \\
\hline TF Forest & 10 & - & 1.90 & - & Sanford (1990) \\
\hline TF Forest & 10 & & 1.00 & - & Sanford (1990) \\
\hline TF Forest & 10 & - & 1.00 & - & Sanford (1990) \\
\hline
\end{tabular}

TF: Terra firme

* Fine root diameter $<5 \mathrm{~mm}$

** FRT as calculated from production and SFR reported for each forest.

${ }^{1}$ FRP was estimated in the same site using rhizotrons with different methods to convert root length into root mass per unit ground area.

2 They make reference to the method used to estimate production: ${ }^{\mathrm{a}}$ maximum-minimum, ${ }^{\mathrm{b}}$ decision matrix, ${ }^{\mathrm{c}}$ flow compartment, and

d decomposition model.

3 Values of SFR are the averages for different forests per landscape unit.

4 They make reference to the method used to estimate production: ${ }^{a}$ ingrowth cores and ${ }^{\mathrm{b}}$ maximum-minimum.

5 These sites were included due their similar conditions with our study sites. 
(5.97 $\mathrm{Mgha}^{-1} \mathrm{yr}^{-1}$ with the ingrowth core method and $6.67 \mathrm{Mg} \mathrm{ha}^{-1} \mathrm{yr}^{-1}$ with sequential cores), while estimations for the clay loam forest are intermediate $\left(3.02 \mathrm{Mg} \mathrm{ha}^{-1} \mathrm{yr}^{-1}\right.$ with ingrowth cores and $2.05 \mathrm{Mg} \mathrm{ha}^{-1} \mathrm{yr}^{-1}, \quad 2.72 \mathrm{Mg} \mathrm{ha}^{-1} \mathrm{yr}^{-1}$ with sequential cores).

The decrease of SFR and FRP with soil depth found here is a general trend reported in tropical forests (Cavelier, 1992; Duivenvoorden and Lips, 1995; Klinge, 1973; Pavlis and Jeník, 2000; Silver et al., 2000) due to the proliferation of fine roots near the surface. These roots are considered important for resource acquisition because they allow the direct cycling of nutrients from organic matter, which probably is an adaptation to the low nutrient supply in infertile soils (Sayer et al., 2006).

Both SFR and FRP were significantly higher in the loamy sand forest than in the clay loam forest. These results show that in loamy sand forest, with lower nutrient contents, below-ground mass allocation is higher than for other forests. This result has been found in other forests on soils with low nutrient availability and content (Cavelier, 1992; Priess et al., 1999), and specifically in sites such as the mountains in Guiana (Priess et al., 1999) and elsewhere in Amazonia (Klinge and Herrera, 1978).

Differences found here between forest types support our hypothesis about the decrease of stocks and production of fine roots with the increase of soil resources and agree with other hypotheses proposing the increase of SFR and carbon allocation below-ground with the decrease of site quality, nutrient availability or under more xerophytic conditions (Shaver and Aber, 1996, Landsberg and Gower, 1997). The investment in leaf compounds, such as tannins, to retard litter decomposition and hence slow down the rate of nutrient cycling, could result in an increase of below-ground productivity to improve the supply of nutrients to the plant (Fischer et al., 2006). These authors found that FRP was highly correlated with leaf tannin content and the genetic composition of individual trees, which suggests a potential genetic control of the compensatory growth of fine roots in response to the accumulation of secondary compounds of foliage in the soil. This is a factor that could be evaluated as a potential mechanism of allocation to below-ground productivity, particularly in sand forests which tend to contain high amounts of tannins in the foliage.

Several studies show that soil plays an important role in the carbon allocation to below-ground production (Block et al., 2006; Cavelier, 1992; Haynes and Gower, 1995; Yavitt and Wright, 2001), and Malhi et al. (2004) found that soil is an important factor affecting above-ground NPP with Quesada et al. (2009c) showing soil available phosphorus availability to be the likely driving variable. Haynes and Gower (1995) analysed how soil fertility affected carbon allocation to below-ground productivity in a plantation of $P i$ nus resinosa Ait. on fertilized and unfertilized soils, and found that fertilization decreased the relative carbon allo- cation to below-ground production. Gower et al. (1992), analysed how the availability of water and nutrients affected the NPP in a coniferous forest (Pseudosuga menziesii var. galuca), and found a negative relationship between water and nutrient availability and carbon allocation to below-ground organs. In the case of the forests studied, the fact that they are subject to the same climatic regime, we conclude that soil is the factor playing the principal role on the amount of carbon allocated to roots. In this way, both SFR and FRP decreased with the increase of soil fertility, which is opposite to the results of Malhi et al. (2004) for above-ground NPP.

On the other hand, integrating above- and below-ground productivity of the forests studied (Table 5) suggests that allocation of NPP between above (wood and foliage)- and below-ground (fine roots) is differential, just as suggested by the differential allocation hypothesis proposes. Even though carbon allocation to the above-ground portion was higher than that to fine roots, this difference is more accentuated in the clay loam forest than in the forest growing on loamy sand. Indeed, differences in the total productivity (above plus below-ground) between the two forests were not high (between 8.66 and $8.76 \mathrm{MgC} \mathrm{ha}^{-1} \mathrm{yr}^{-1}$ for the clay loam forest and, $7.12 \mathrm{MgC} \mathrm{ha}^{-1} \mathrm{yr}^{-1}$ for the loamy sand forest). These results on above- and below-ground productivity show the large variation of Amazonian forests at smaller scales than that presented by Malhi et al. (2004), which reflects the importance of soil and widen the knowledge about the allocation to above- and below-ground productivity in different forest types and soils of the Amazon region (see Aragão et al., 2009).

\subsection{Turnover rates of fine roots}

Turnover rates of this study $\left(0.51-0.84 \mathrm{yr}^{-1}\right)$ are similar to values reported for other Amazonian forests (0.14 and $0.70 \mathrm{yr}^{-1}$ ) (Table 4). Nevertheless, the average turnover rate for the plot AGP-01 in the loamy soil forest was comparatively high $\left(0.84 \mathrm{yr}^{-1}\right)$. Fine roots are tissues energetically expensive to build (Yavitt and Wright, 2001) and their longevity is critical for the functionality of the root system. Short longevity supposes higher energetic demands for the formation of new roots to replace dead roots and to maintain the concomitant absorption surface. Aber et al. (1985) propose that turnover rates of fine roots are higher on rich soils than on poor ones. However, turnover rates in both forest types showed similar values $\left(0.53-0.84 \mathrm{yr}^{-1}\right.$ for the clay loam forest, and $0.51-0.81 \mathrm{yr}^{-1}$ for the forest on white sands). The large variability of turnover rates in each forest type could mask differences between them.

\subsection{Temporal variation of standing crop fine root mass}

Several authors have correlated environmental variables with biomass or production of fine roots (Gower et al., 1992; Kavanagh and Kellman, 1992; Vogt et al., 1998; Yavitt and 
Table 5. Above- and below-ground productivity $\left(\mathrm{MgCha}^{-1} \mathrm{yr}^{-1}\right)$ in two forests with different soil types in the Colombian Amazon: one forest on clay loam soil in the Amacayacu National Natural Park (two 1-ha plots: AGP-01 and AGP-02), and other on loamy sands in the Biological Station Zafire (one 1-ha plot: ZAR-01).

\begin{tabular}{|c|c|c|c|}
\hline \multirow{2}{*}{ Productivity ( $\left.\mathrm{MgC} \mathrm{ha}^{-1} \mathrm{yr}^{-1}\right)$} & \multicolumn{2}{|c|}{ Clay loam forest } & \multirow{2}{*}{$\begin{array}{r}\text { Loamy sand forest } \\
\text { ZAR-01 }\end{array}$} \\
\hline & AGP-01 & AGP-02 & \\
\hline \multicolumn{4}{|l|}{ Above-ground productivity } \\
\hline Wood productivity ${ }^{\mathrm{a}}$ & 3.35 & 3.84 & 1.32 \\
\hline Litterfall production $b$ & $3.87 \mathrm{a}$ & $3.65 \mathrm{a}$ & $2.67 b$ \\
\hline Total & 7.22 & 7.49 & 3.99 \\
\hline \multicolumn{4}{|c|}{ Below-ground productivity (fine roots) ${ }^{c}$} \\
\hline Ingrowth cores & \multicolumn{2}{|c|}{1.51} & 2.94 \\
\hline Sequential soil coring & 1.36 & 1.03 & 3.33 \\
\hline Mean & 1.44 & 1.27 & 3.14 \\
\hline Total productivity & 8.66 & 8.76 & 7.13 \\
\hline
\end{tabular}

${ }^{a}$ E. M. Jiménez and M. C. Peñuela (data not published). ${ }^{b}$ Navarrete (2006). ${ }^{c}$ Mean production, results from the present study. Different letters show significant differences $(p<0.05)$.

Wright, 2001). Among these variables, rainfall has been found to be one of the most influential factors affecting SFR and its longevity in tropical forests (Green et al., 2005). Standing crop fine root mass showed a clear temporal variation during the monitoring period, a result in line with numerous studies showing that for certain periods of the year a higher growth rate of fine roots occurs in response to specific climatic events (Vogt et al., 1986). Though results suggest that differences in carbon allocation to production of fine roots between forest types are governed by the availability of soil resources, patterns of temporal variation of SFR are explained by their correlation with rainfall, which has been reported for other tropical forests (Green et al., 2005; Kavanagh and Kellman, 1992; Yavitt and Wright, 2001).

Though SFR responded to the average daily rainfall in both forest types, these responses were of a contrasting nature. For the loamy soil forest soil plot SFR increased with rainfall of the last three months and decreased with rainfall occurring over long time lags (120-150 days). In the forest on white sands SFR decreased with rainfall of the previous 4 months, and increased with the rainfall observed at longer time lags (up to 5 months). Differences of the response of both forest types to rainfall might be explained by differences in their soils: the loamy sand forest contained a hard pan at $90-100 \mathrm{~cm}$ depth, which inevitably produces water logging in the soil above during rainy season and likely impeding growth of fine roots; this is shown by the negative correlation of SFR with rainfall of last 4 months. This phenomenon does not occur in the clay loam soil forest which responds positively to the increase of rainfall.

On the other hand, the effect of rainfall on FRP was evident in the drought season of 2005. RGR during the drought showed that both forests responded in similar way, because both showed a decrease in FRP. However, for the loamy sand forest this decrease was more obvious over the last months of the drought (Fig. 5). The impermeable orstenic layer of the Podzol soil probably plays an important role in the soil water content of this forest by causing water retained above it during the rainy season to only be slowly released during the dry season, and therefore delaying the forest response to the drought. The general behaviour during drought suggests that both forest types are susceptible to strong changes of rainfall. However, the main difference between them is the speed of the response of each forest: the clay loam forest showed a faster decrease of FRP as a response to drought than the loamy sand forest. Due to this differential response of two forest types to drought we can not compare FRP between forests to dry season.

Likewise, in both forest types RGR before drought were higher than after drought. This probably is related with the higher rainfall of last months before the first collections (year 2004), than that after the drought, in 2006 (Fig. 4). In the clay loam forest of AGP-01, the periods between collections that showed an increase of SFR were October-December 2005, and September-December 2006, which coincided with the rainy season. Also in AGP-02 October-December 2005 was the period of increase of SFR. In both plots the SFR was higher in December 2005 than in the same month of 2006, which could be explained by the higher rainfall of the two previous months in 2005 than in 2006 (Fig. 2).

In the loamy sand forest the periods of increase of the SFR occurred between April-July 2005, and March-July 2006, when rainfall decreased and we suggests because the water logging of soil caused by the hardpan also decreased. On 
Table 6. Spearman coefficients $\left(r_{s}\right)$ for the standing crop fine root mass in two forests with different soil types in the Colombian Amazon, correlated with the mean precipitation per day (PD) of the last 7, 15, 30, 60, 90, 100 and 120 days until the date of collection and, with the mean precipitation per day with a time lag (TL) of 7, 15, 30, 120 and 150 days from the date of collection with fixed intervals of time of 15 , 30,60 and 90 days.

\begin{tabular}{|c|c|c|c|}
\hline \multirow{2}{*}{ Mean precipitation $\left(\mathrm{mm} \mathrm{day}^{-1}\right)$} & \multicolumn{2}{|c|}{ Clay loam forest } & \multirow{2}{*}{$\begin{array}{r}\text { Loamy sand forest } \\
\text { ZAR-01 }\end{array}$} \\
\hline & AGP-01 & AGP-02 & \\
\hline PD-7 & -0.0844 & -0.0244 & $-0.2581 * *$ \\
\hline PD-15 & -0.0560 & 0.0691 & $-0.2872 * *$ \\
\hline PD-30 & -0.0118 & 0.1700 & -0.1414 * \\
\hline PD-60 & 0.1479 & $0.3052 * *$ & $-0.2857 * *$ \\
\hline PD-90 & $0.2169 *$ & $0.3422 * *$ & $-0.1612 *$ \\
\hline PD-100 & 0.1721 & $0.2397 *$ & $-0.1544 *$ \\
\hline PD-120 & 0.1492 & $0.2397 *$ & $-0.1294 *$ \\
\hline TL7-15 & 0.1835 & $0.4666^{* *}$ & $-0.3223^{* *}$ \\
\hline TL7-30 & 0.0455 & $0.3548 * *$ & $-0.1502 *$ \\
\hline TL7-60 & $0.2190 *$ & $0.4702 * *$ & $-0.2769 * *$ \\
\hline TL7-90 & $0.2397 *$ & $0.2845^{* *}$ & -0.1222 \\
\hline TL15-15 & 0.0068 & 0.1314 & 0.0555 \\
\hline TL15-30 & 0.0142 & $0.2494 *$ & -0.0240 \\
\hline TL15-60 & $0.2015 *$ & $0.3422 * *$ & -0.1168 \\
\hline TL15-90 & 0.1884 * & 0.1820 & -0.1100 \\
\hline TL30-15 & 0.1417 & $0.2512 *$ & -0.1563 * \\
\hline TL30-30 & 0.1195 & 0.1941 & $-0.2261^{* *}$ \\
\hline TL30-60 & $0.2060 *$ & 0.1820 & $-0.1652 *$ \\
\hline TL30-90 & 0.1831 & 0.1820 & -0.0601 \\
\hline TL120-15 & $-0.2813^{* *}$ & $-0.2653 *$ & -0.0779 \\
\hline TL120-30 & $-0.3719^{* *}$ & $-0.2805 *$ & $-0.1562 *$ \\
\hline TL120-60 & $-0.3260^{* *}$ & $-0.2603 *$ & -0.1283 \\
\hline TL120-90 & $-0.2775^{* *}$ & $-0.3871^{* *}$ & 0.0923 \\
\hline TL150-15 & $-0.3369^{* *}$ & -0.0254 & 0.1179 \\
\hline TL150-30 & $-0.2834^{* *}$ & $-0.2777^{*}$ & $0.1943^{* *}$ \\
\hline TL150-60 & $-0.2627^{* *}$ & $-0.3449^{* *}$ & 0.1657 * \\
\hline TL150-90 & $-0.2593^{* *}$ & $-0.4480^{* *}$ & 0.1120 \\
\hline
\end{tabular}

* Significance level $p<0.05 .{ }^{* *}$ Significance level $p<0.01$

the other hand, SFR was higher in July 2005 than in July 2006, which can be explained by the decrease in the soil water logging in July 2005 when the first months of drought occurred, which allowed an increase of SFR. The two preceding months to July 2006 showed a mean rainfall higher than in 2005, which suggests that water logging conditions of soil were greater at this time than in 2005, which was expressed in a lesser SFR.

Our results thus show that rainfall plays a crucial role in the seasonal variation of fine root growth in both forests; in the clay loam soil forest the pattern accords with reports for other well drained forests (Green et al., 2005; Metcalfe et al., 2008; Priess et al., 1999; Silver et al., 2005), where SFR increased in the rainy season and decreases during the dry season. The loamy sand forest showed a different pattern, similar to that of flooded forests. This behaviour is apparently conditioned by the hardpan (orstenic layer) that causes water logging during the rainy season thus limiting growth of fine roots and lagging the timing of fine root growth in response to rainfall.

\subsection{The methods of sampling/estimation used}

The selection of methods for the estimation of FRP and its controlling factors is tremendously important and has raised great interest nowadays (Hendricks et al., 2006; Lauenroth et al., 1986; Majdi et al., 2005; Makkonen and Helmisaari, 
1999; Metcalfe et al., 2007; Vogt et al., 1986, 1998). Hendricks et al. (2006), used a wide range of common methods to estimate FRP in three types of ecosystems in a gradient of soil humidity, with different soil characteristics and resource availability. They found that FRP was not negatively correlated with the availability of soil resources. Their results support in some cases the hypothesis of differential resource allocation and in some others the constant allocation hypothesis. With respect to the methods used in the present study - sequential cores and the ingrowth cores - these authors mention, as well as others (Madji et al., 2005; Vogt et al., 1986, 1998), that they probably underestimate FRP; however, they seem to be the most appropriate to compare sites and to evaluate the temporal variation of FRP and SFR (Vogt et al., 1998; Makkonen and Helmisaari, 1999).

We acknowledge that sampling differences have the potential to bias the results of this study. On the one hand, sample sizes might not have a significant effect because they were almost identical in both forest types ( 22 vs. 26 in the establishment 2, and 13 vs. 13 in the establishment 3 in the loamy sand forest and clay loam forest, respectively). On the other hand, the main potential limitation of our sampling scheme is the effect on FRP of different core sizes in the ingrowth experiment. The use of two independent methods to estimate FRP (ingrowth and sequential cores), allowed us to crosscheck our results. Sequential cores are samples of fine root mass under the natural conditions of the site and their results are expected to be little affected by the diameters of cores, as expected in ingrowth cores due to the differential colonization of roots.

Results of FRP and its temporal variation did not show large differences between the two methods used here in each forest type. The clay loam forest showed similar results of SFR between the two methods, but differences in the loamy sand forest were marked: SFR estimated by the ingrowth cores was about $5.00 \mathrm{Mg} \mathrm{ha}^{-1}$, while by the sequential cores was about twice that value $\left(10.94 \mathrm{Mgha}^{-1}\right)$. This result suggests that probably more important than the diameter of auger, there is a strong effect of the changed physical properties of soil on root growth in loamy sands and that those soils require a longer time to reach the original root density after the disturbance implied by the ingrowth method.

Despite the different results of FRP obtained with the different methods as widely documented by several authors (Hendricks et al., 2006; Vogt et al., 1998), all of them continue being used because of the lack of consensus about the most appropriate one to study the dynamics of fine roots. For these reasons, the combination of different methods used here seems to be a good strategy for the estimation of FRP.

\section{Conclusions}

Carbon allocation to production of fine roots fine roots was different between forest types. As expected in a gradient of availability of soil resources, the clay loam soil forest, with less limitation in soil resources, showed a lower carbon allocation to production of fine roots than the loamy sand forest which had more limitations in soil resource availability. SFR and FRP also showed differences with soil depth, with higher values in the first $10 \mathrm{~cm}$ than in the $10-20 \mathrm{~cm}$ layer of soil.

Temporal variation of SFR was correlated with mean daily rainfall; however, this inverse relationship was between forest types: in the clay loam soil forest SFR increased with the increase of rainfall of the previous three months; in the loamy sand forest SFR decreased with the increase of rainfall of the previous four months. Likewise, RGR of fine roots were different before, during, and after the drought period. Both forest types showed lower RGR during drought, which suggests that severe changes of rainfall could strongly affect both forest types.

In summary, from results shown here we can say that this study: (1) that the amount and fraction of carbon allocated to fine roots was different between plots, (2) that there are differences in NPP allocation at these plots, (3) suggests that probably Total NPP (above plus below-ground) was not very different between the plots, and (4) a strong cautionary warning is provided against assuming that patterns of total ecosystem NPP can be adequately understood/studied solely from above-ground NPP.

Finally, this study shows that variation in the functioning of Amazonian ecosystems at small spatial and time scales is large; it also shows that both rainfall patterns and soils act in different ways on the carbon allocation to production of fine roots in these forests and that understanding how Amazonian ecosystems can respond to these factors is fundamental considering the events expected by climate change.

Acknowledgements. This paper is a product of the RAINFOR network and Pan-Amazonia project from University of Leeds. RAINFOR is currently supported by the Gordon and Betty Moore Foundation. This work was supported also by the Amazon Drought project of the University of Leeds, the Zafire Biological Station and the project "Saber y Gestión Ambiental Amazónica" of the Universidad Nacional de Colombia Sede Amazonia. We also wish to thank to E. Álvarez, D. Navarrete and O. Phillips for their contribution to this research, A. Prieto and A. Rudas who made it possible to work in the plots in Amacayacu Natural Park and especially C. A. Quesada who generously shared his information on soils of the sites studied. We also thank to the indigenous communities of Palmeras and San Martín of Amacayacu and the staff of the Amacayacu National Natural Park and the crew of the Zafire Biological Station, especially Eufrasia Kuyuedo, Arcesio Pijachi, Edilberto Rivero, Angel Pijachi, Iván Niño, Ilmer Niño, Zulma Alban and Magnolia Restrepo, and the Universidad Nacional de Colombia Sede Amazonia by permitting and facilitating the fieldwork. Finally, we thank to D. Metcalfe, S. Vasconcelos and P. Meir for valuable suggestions and comments to improve the manuscript.

Edited by: P. Meir 


\section{References}

Aber, J. D., Melillo, J. M., Nadelhoffer, K. J. McClaugherty, C. A., and Pastor, J.: Fine root turnover in forest ecosystems in relation to quantity and form of nitrogen availability: a comparison of two methods, Oecologia, 66, 317-321, 1985.

Albaugh, T. J., Allen, H. L., Dougherty, P. M., Kress, L. W., and King, J. S.: Leaf area and above-and below-ground growth responses of loblolly pine to nutrient and water additions, Forest Sci., 44, 317-328, 1998.

Aragão, L. E. O. C., Malhi, Y., Metcalfe, D. B., Silva-Espejo, J. E., Jiménez, E., Navarrete, D., Almeida, S., Costa, A. C. L., Salinas, N., Phillips, O. L., Anderson, L. O ., Baker, T. R., Goncalvez, P. H., Huamán-Ovalle, J., Mamani-Solórzano, M., Meir, P., Monteagudo, A., Peñuela, M. C., Prieto, A., Quesada, C. A., Rozas-Dávila, A., Rudas, A., Silva Junior, J. A., and Vásquez, R.: Above- and below-ground net primary productivity across ten Amazonian forests on contrasting soils, Biogeosciences Discuss., 6, 2441-2488, 2009,

http://www.biogeosciences-discuss.net/6/2441/2009/.

Block, R. M. A., Van Rees, K. C. J., and Knight, J. D.: A review of fine root dynamics in Populus plantations, Agroforest. Syst., 67, 73-84, 2006.

Brown, S.: Measuring carbon in forests: current status and future challenges, Environ. Pollut., 116(3), 363-372, 2002.

Cavelier, J.: Fine-root biomass and soil properties in a semideciduous and a lower montane rain-forest in Panama, Plant Soil, 142, 187-201, 1992.

Clark, D. A., Brown, S., Kicklighter, D. W., Chambers, J. Q., Thomlinson, J. R., Ni, J., and Holland, E. A.: Net primary production in tropical forests: An evaluation and synthesis of 20 existing field data, Ecol. Appl., 11, 371-384, 2001a.

Clark, D. A., Brown, S., Kicklighter, D. W., Chambers, J. Q., Thomlinson, J. R., and Ni, J.: Measuring net primary production in forests: Concepts and field methods, Ecol. Appl., 11, 356-370, 2001b.

Cuevas, E. and Medina, E.: Nutrient dynamics within Amazonian forest ecosystems, I. Nutrient 25 flux in fine litter fall and efficiency of nutrient utilization, Oecologia, 68, 466-472, 1986.

Cuevas, E. and Medina, E.: Nutrient dynamics within Amazonian forests. II. Fine root growth, nutrient availability and leaf litter decomposition, Oecologia, 76, 222-235, 1988.

Dixon, R. K., Brown, S., Houghton, R. A., Solomon, A. M., Trexler, M. C., and Wisniewski, J.: Carbon pools and flux of global forest ecosystems, Science, 263, 185-190, 1994.

Duivenvoorden, J. F. and Lips, J. M.: A land-ecological study of soils, vegetation, and plant diversity in Colombian Amazonia. The Tropenbos Foundation, Wageningen, Netherlands, 438 pp., 1995.

Dytham, C.: Choosing and using statistics. A biologist's guide, Blackwell Publishing, 2nd edn. Oxford, UK, 248 pp., 2003.

Fischer, D. G., Hart, S. C., Rehill, B. J., Lindroth, R. L., Keim, P., and Whitham, T. G.: Do high-tannin leaves require more roots?, Oecologia, 149, 668-675, 2006.

Fogg, G. E.: El crecimiento de las plantas, Editorial Eudeba, Buenos Aires, Argentina, 327 pp., 1967.

Goward, S. N., Dye, D. G., Turner, S., and Yang, J.: Objective assessment of the NOAA global vegetation index data product, Int. J. Remote Sens., 14, 3365-3394, 1993.
Gower, S. T.: Relations between mineral nutrient availability and fine root biomass in two Costa Rican tropical wet forests: a hypothesis, Biotropica, 19, 171-175, 1987.

Gower, S. T., Vogt, K. A., and Grier, C. C.: Carbon dynamics of rocky-mountain Douglas-fir - 10 influence of water and nutrient availability, Ecol. Monogr., 62, 43-65, 1992.

Green, J. J., Dawson, L. A., Proctor, J., Duff, E. I., and Elston, D. A.: Fine root dynamics in a tropical rain forest is influenced by rainfall, Plant Soil, 276, 23-32, doi:10.1007/s11104-004-0331$3,2005$.

Grier, C. C., Vogt, K. A., Keyes, M. R., and Edmonds, R. L.: Biomass distribution and above and below-ground production in young and mature Abies amabilis zone ecosystems of the Washington Cascades, Can. J. Forest Res., 11, 155-167, 1981.

Haynes, B. E. and Gower, S. T.: Below-ground carbon allocation in unfertilized and fertilized red pine plantations in Northern Wisconsin, Tree Physiol., 15, 317-325, 1995.

Hendricks, J. J., Hendrick, R. L., Wilson, C. A., Mitchell, R. J., Pecot, S. D., and Guo, D. L.: As sessing the patterns and controls of fine root dynamics: an empirical test and methodological review, J. Ecol., 94, 40-57, 2006.

Hendricks, J. J., Nadelhoffer, K. J., and Aber, J. D.: Assessing the role of fine roots in carbon and nutrient cycling, Trends Ecol. Evol., 8, 174-178, 1993.

Herrera, J.: Geografía, in: Zonificación ambiental para el plan modelo Colombo-Brasilero (Eje Apaporis-Tabatinga: PAT), Instituto Geográfico Agustín Codazzi -IGAC, Bogotá, Colombia, 137163, 1997.

Hoorn, C.: An environmental reconstruction of the paleo-Amazon River system (Middle-Late Miocene, NW Amazonia), Palaeogeogr. Palaeocl., 112, 187-238, 1994.

Hoorn, C.: Mangrove forests and marine incursions in Neogene Amazonia (Lower Apaporis River, Colombia), Palaios, 21, 197209, 2006.

Jackson, R. B., Mooney, H. A., and Schulze, E. D.: A global budget for fine root biomass, surface area, and nutrient contents, Ecology, 94, 7362-7366, 1997.

Jordan, C. F. and Escalante, G.: Root productivity in an Amazonian rain forest, Ecology, 61, 14-18, 1980.

Kavanagh, T. and Kellman, M.: Seasonal pattern of fine root proliferation in a tropical dry forest, Biotropica, 24, 157-165, 1992.

Keyes, M. R. and Grier, C. C.: Above- and below-ground net production in 40-year-old Douglas-fir stands on low and high productivity sites, Can. J. Forest Res., 11, 599-605, 1981.

Klinge, H. and Herrera, R.: Biomass studies in Amazon Caatinga forest in southern Venezuela. I. Standing crop of composite root mass in selected stands, Tropical Ecology, 19, 93-110, 1978.

Klinge, H.: Root mass estimation in lowland tropical rain forests of Central Amazon, Brazil. I. Fine root masses of a pale yellow latosol and a giant humus podzol, Tropical Ecology, 14, 29-38, 1973.

Kozlowski, T. T., Kramer, P. J., and Pallardi, S. G.: The physiological ecology of woody plants, Academic Press, San Diego, California, USA, 657 pp., 1991.

Landsberg, J. J. and Gower, S. T.: Applications of physiological ecology to forest management, in: Physiological Ecology, edited by: Mooney, H. A., Academic Press, San Diego, USA, 354 pp., 1997. 
Lauenroth, W. K., Hunt, H. W., Swift, D. M., and Sing, J. S.: Reply to Vogt et al., Ecology, 67, 580-582, 1986.

Majdi, H., Pregitzer, K., Moren, A. S., Nylund, J. E. M., and Agren, G. I.: Measuring fine root turnover in forest ecosystems, Plant Soil, 276, 1-8, 2005.

Makkonen, K. and Helmisaari, H. S.: Assessing fine-root biomass and production in a Scots pine stand-comparison of soil core and root ingrowth core methods, Plant Soil, 210, 43-50, 1999.

Malhi, Y., Baker, T. R., Phillips, O. L., Almeida, S., Alvarez, E., Arroyo, L., Chave, J., Czimczik, C., Di Fiore, A., Higuchi, N., Killeen, T., Laurance, S. G., Laurance, W. F., Lewis, S. L., Mercado, L. M., Monteagudo, A., Neill, D. A., Pitman, N. C. A., Quesada, C. A., Silva, J. N. M., Vásquez Martínez, R., Terborgh, J., Vinceti, B., and Lloyd, J.: The above-ground wood productivity and net primary productivity of 100 Neotropical forests, Global Change Biol., 10, 563-591, 2004.

Metcalfe, D. B., Meir, P., and Williams, M.: A comparison of methods for converting rhizotron root length measurements into estimates of root mass production per unit ground area, Plant Soil, 301, 279-288, 2007.

Metcalfe, D. B., Meir, P., Aragão, L. E., Da Costa, A. C. L., Braga, A. P., Gonçalves, P. H. L., De Athaydes Silva Jr., J., De Almeida, S. S., Dawson, L. A., Malhi, Y., and Williams, M.: The effects of water availability on root growth and morphology in an Amazon rainforest, Plant Soil, 311, 189-199, 2008.

Nadelhoffer, K. J. and Raich, J. W.: Fine root production estimates and belowground carbon allocation in forest ecosystems, Ecology, 73, 1139-1147, 1992.

Nadelhoffer, K. J., Aber, J. D., and Melillo, J. M.: Fine roots, net primary production, and soil nitrogen availability-a new hypothesis, Ecology, 66, 1377-1390, 1985.

Navarrete, D. A.: Variación de la caída de la hojarasca fina a través de diferentes tipos de suelos y regiones en la Amazonia, Master Thesis in Amazon studies, Universidad Nacional de Colombia, Sede Amazonia, Leticia, Colombia, 86 pp., 2006.

Patiño, S., Lloyd, J., Paiva, R., Baker, T. R., Quesada, C. A., Mercado, L. M., Schmerler, J., Schwarz, M., Santos, A. J. B., Aguilar, A., Czimczik, C. I., Gallo, J., Horna, V., Hoyos, E. J., Jimenez, E. M., Palomino, W., Peacock, J., Peña-Cruz, A., Sarmiento, C., Sota, A., Turriago, J. D., Villanueva, B., Vitzthum, P., Alvarez, E., Arroyo, L., Baraloto, C., Bonal, D., Chave, J., Costa, A. C. L., Herrera, R., Higuchi, N., Killeen, T., Leal, E., Luizão, F., Meir, P., Monteagudo, A., Neil, D., NúñezVargas, P., Peñuela, M. C., Pitman, N., Priante Filho, N., Prieto, A., Panfil, S. N., Rudas, A., Salomão, R., Silva, N., Silveira, M., Soares deAlmeida, S., Torres-Lezama, A., Vásquez-Martínez, R., Vieira, I., Malhi, Y., and Phillips, O. L.: Branch xylem density variations across the Amazon Basin, Biogeosciences, 6, 545-568, 2009,

http://www.biogeosciences.net/6/545/2009/.

Pavlis, J. and Jenik, J.: Roots of pioneer trees in the Amazonian rain forest, Trees-Struct. Funct., 14, 442-455, 2000.

Phillips, O. L., Aragão, L. E. O. C. , Lewis, S. L., Fisher, J. B., Lloyd, J., López-González, G., Malhi, Y., Monteagudo, A., Peacock, J., Quesada, C. A., Van Der Heijden, G., Almeida, S., Amaral, I., Arroyo, L., Aymard, G., Baker, T. R., Bánki, O., Blanc, L., Bonal, D., Brando, P., Chave, J., Alves De Oliveira, A. C., Dávila Cardozo, N., Czimczik, C. I., Feldpausch, T. R., Freitas, M. A., Gloor, E., Higuchi, N., Jiménez, E. M., Lloyd,
G., Meir, P., Mendoza, C., Morel, A., Neill, D. A., Nepstad, D., Patiño, S. Peñuela, M. C., Prieto, A., Ramírez, F., Schwarz, M., Silva, J., Silveira, M., Sota Thomas, A., Ter Steege, H., Stropp, J., Vásquez, R., Zelazowski, P., Alvarez Dávila, E., Andelman, S., Andrade, A., Chao, K. J., Erwin, T., Di Fiore, A., Honorio C., E., Keeling, H., Killeen, T. J., Laurance, W. F., Peña Cruz, A., Pitman, N. C. A., Núñez Vargas, P., Ramírez-Angulo, H., Rudas, A., Salamão, R., Silva, N., Terborgh, J., and Torres-Lezama, A.: Drought Sensitivity of the Amazon Rainforest, Science, 323, 1344-1347, 2009.

Priess, J., Then, C., and Folster, H.: Litter and fine-root production in three types of tropical premontane rain forest in SE Venezuela, Plant Ecol., 143, 171-187, 1999.

PRORADAM: La Amazonia Colombiana y sus recursos. Proyecto radargramétrico del Amazonas, República de Colombia, Bogotá, 590 pp., 1979.

Quesada, C. A., Lloyd, J., Anderson, L. O., Fyllas, N. M., Schwarz, M., and Czimczik, C. I.: Soils of amazonia with particular reference to the rainfor sites, Biogeosciences Discuss., 6, 3851-3921, 2009a, http://www.biogeosciences-discuss.net/6/3851/2009/.

Quesada, C. A., Lloyd, J., Schwarz, M., Patiño, S., Baker, T. R., Czimczik, C., Fyllas, N. M., Martinelli, L., Nardoto, G. B., Schmerler, J., Santos, A. J. B., Hodnett, M. G., Herrera, R., Luizão, F. J., Arneth, A., Lloyd, G., Dezzeo, N., Hilke, I., Kuhlmann, I., Raessler, M., Brand, W. A., Geilmann, H., Moraes Filho, J. O., Carvalho, F. P., Araujo Filho, R. N., Chaves, J. E., Cruz Junior, O. F., Pimentel, T. P., and Paiva, R.: Chemical and physical properties of Amazon forest soils in relation to their genesis, Biogeosciences Discuss., 6, 3923-3992, 2009b,

http://www.biogeosciences-discuss.net/6/3923/2009/.

Quesada, C. A., Lloyd, J., Schwarz, M., Baker, T. R., Phillips, O. L., Patiño, S., Czimczik, C., Hodnett, M. G., Herrera, R., Arneth, A., Lloyd, G., Malhi, Y., Dezzeo, N., Luizão, F. J., Santos, A. J. B., Schmerler, J., Arroyo, L., Silveira, M., Priante Filho, N., Jimenez, E. M., Paiva, R., Vieira, I., Neill, D. A., Silva, N., Peñuela, M. C., Monteagudo, A., Vásquez, R., Prieto, A., Rudas, A., Almeida, S., Higuchi, N., Lezama, A. T., López-González, G., Peacock, J., Fyllas, N. M., Alvarez Dávila, E., Erwin, T., di Fiore, A., Chao, K. J., Honorio, E., Killeen, T., Peña Cruz, A., Pitman, N., Núñez Vargas, P., Salomão, R., Terborgh, J., and Ramírez, H.: Regional and large-scale patterns in Amazon forest structure and function are mediated by variations in soil physical and chemical properties, Biogeosciences Discuss., 6, 39934057, 2009c,

http://www.biogeosciences-discuss.net/6/3993/2009/.

Raich, J. W. and Nadelhoffer, R. J.: Below-ground carbon allocations in forest ecosystems: Global trends, Ecology, 70, 13461354, 1989.

Rudas-Ll., A. and Prieto-C., A.: Flórula del Parque Nacional Natural AMACAYACU, Amazonas, Colombia, Monographs in Systematic Botany from the Missouri Botanical Garden, 99, Missouri Botanical Garden, Saint Louis, Missouri, 2005.

Sayer, E. J., Tanner, E. V. J., and Cheesman, A. W.: Increased litterfall changes fine root distribution in a moist tropical forest, Plant Soil, 281, 5-13, 2006.

Shaver, G. R. and Aber, J. D.: Carbon and nutrient allocation in terrestrial ecosystems, in: Global change: effects on coniferous forests and grasslands Melillo, edited by: Breymeyer, J. and 
Breymeyer, A., John Wiley, New York, USA, 183-198, 1996.

Silver, W. L., Neff, J., McGroddy, M., Veldkamp, E., Keller, M., and Cosme, R.: Effects of soil texture on below-ground carbon and nutrient storage in a lowland Amazonian forest ecosystem, Ecosystems, 3, 193-209, 2000.

Silver, W. L., Thompson, A. W., Mcgroddy, M. E., Varner, R. K., Dias, J. D., Silva, H., Crill, P. M., and Keller, M.: Fine root dynamics and trace gas fluxes in two lowland tropical forest soils, Global Change Biol., 11, 290-306, 2005.

Trumbore, S., Da Costa, E. S., Nepstad, D. C., De Camargo, P. B., Martinelli, L., Ray, D., Restom, T., and Silver, W.: Dynamics of fine root carbon in Amazonian tropical ecosystems and the contribution of roots to soil respiration, Global Change Biol., 12, 217-229, 2006.

Vogt, K. A., Grier, C. C., and Vogt, D. J.: Production, turnover, and nutrient dynamics in above-and below-ground detritus of world forests, Adv. Ecol. Res., 15, 303-377, 1986.

Vogt, K. A., Grier, C. C., Meier, C. E., and Keyes, M. R.: Organic matter and nutrient dynamics in forest floors of young and mature Abies amabilis stands in western Washington, as affected by fineroot input, Ecol. Monogr., 53, 139-157, 1983.

Vogt, K. A., Vogt, D. J., and Bloomfield, J.: Analysis of some direct and indirect methods for estimating root biomass and production of forests at an ecosystem level, Plant Soil, 200, 71-89, 1998.
Vogt, K. A., Vogt, D. J., Moore, E. E., and Sprugel, D. G.: Methodological considerations in measuring biomass, production, respiration and nutrient resorption for tree roots in natural ecosystems, in: Applications of continuous and steady-state methods to root biology, edited by: Torrey, J. G. and Winship, L. J., Kluwer Academic Publishers, Dordrecht, The Netherlands, 217-232, 1989.

Vogt, K. A., Vogt, D. J., Moore, E. E., Littke, W., Grier, C. C., and Leney, L.: Estimating Douglasfir fine root biomass and production from living bark and starch, Can. J. Forest Res., 15, 177$179,1985$.

Vogt, K. A., Vogt, D. J., Palmiotto, P. A., Boon, P., O’Hara, J., and Asbjornsen, H.: Review of root dynamics in forest ecosystems grouped by climate, climatic forest type and species, Plant Soil, 187, 159-219, 1996.

Woodward, F. I. and Osborne, C. P.: Research Review: the representation of root processes in models addressing the responses of vegetation to global change, New Phytol., 147, 223-232, 2000.

World Reference Base for Soil Resources: A framework for international classification, correlation and communication, World Soil Resources Report 103, FAO, Rome, 2006.

Yavitt, J. B. and Wright, S. J.: Drought and irrigation effects on fine root dynamics in a tropical moist forest, Panama, Biotropica, 33 , 421-434, 2001. 